Franciszer SiKora

(Kraków)

\title{
Zaginione dokumenty Kazimierza Wielkiego dla odbiorców z ziemi krakowskiej
}

\section{Die verlorenen Dokumente von Kasimir dem Großen für die Bewohner des Krakauer Gebiets}

1. Wprowadzenie. 2. Charakterystyka zawartych w księgach sądowych informacji o dokumentach. 3. Czterdzieści zaginionych dokumentów - opisy.

1. Einleitung. 2. Charakteristik der in den Gerichtsbüchern enthaltenen Informationen über die Dokumente. 3. Vierzig verlorene Dokumente - Beschreibungen.

Obecnie imponująco prezentuje się dorobek nauki historycznej w zakresie wydawnictw średniowiecznych dokumentów polskich, w tym przede wszystkim małopolskich (głównie do r. 1450). Nie miejsce tu na szczegółowe omówienie tych wydawnictw, nie można jednak nie wymienić wyjątkowo zasłużonych dla Malopolski wydawców w osobach Franciszka Piekosińskiego, z jego kodeksami, oraz Ireny Sułkowskiej-Kuraś i Stanisława Kurasia, z ich zbiorami dokumentów ${ }^{1}$.

Wydawcy Zbioru dokumentów malopolskich przeprowadzili wyjątkowo szeroką kwerendę i poszukiwania w licznych zbiorach archiwalnych, co przyniosło nadspodziewanie obfity plon. Nawet w wykorzystanych przez F. Piekosińskiego zespołach odnaleźli sporo niedrukowanych dokumentów, gdyż często nie wydawał on wszystkich znajdujących się w nich dyplomów do roku 1450 . Wspomniani wydawcy Zbioru nie ograniczali się przy tym do wydawania aktów zachowanych w calości, ale skrupulatnie zebrali $\mathrm{z}$ lustracji królewszczyzn i opublikowali liczne wzmianki o nieistniejących dziś dokumentach lokacyjnych oraz kontraktach sołeckich i wójtowskich. Wzmianki te z reguly zawierają datę, imię wystawcy i krótką treść. Dane te spisywano $\mathrm{z}$ przedstawianych komisarzom lustracyjnym dokumentów. Co prawda, pomijano imię formalnego odbiorcy, ale właściwie zastępuje go nazwa wsi,

\footnotetext{
${ }^{1}$ Zob. KDK, KDM i ZDM w wykazie skrótów zamieszczonych na s. 45.
} 
której lokacji lub przeniesienia na prawo niemieckie dotyczył dany dyplom monarszy ${ }^{2}$. Wspomniani wydawcy nie uwzględniali wzmianek o dokumentach w księgach sądowych województwa krakowskiego. Nie możne tu jednak być mowy o formulowaniu z tego powodu jakichkolwiek zarzutów, gdyż żmudna i czasochłonna kwerenda w tych księgach nie przystawalaby w żaden sposób do jej rezultatów. Wzmianki w księgach sądowych wskazują konkretnego wystawce - księcia lub króla, i ogólnikowo informują o treści fragmentu wiążącego się ściśle z toczącą się aktualnie sprawą sądową. Nierzadkie były jednak przypadki cytowania sporego fragmentu dyspozycji dotyczącego przede wszystkim immunitetu sądowego. Pisarze sądowi konsekwentnie nie odnotowywali niestety dat okazywanych przez strony procesowe w sądzie dokumentów. Nie wskazywali też odbiorcy dokumentu monarszego, ale i w tym wypadku nieformalną rolę odbiorcy w przypadku dokumentów lokacyjnych poniekąd pełniła wieś lub miasto, którego dotyczył dany dokument. W kilkunastu jednak przypadkach można mówić o konkretnych odbiorcach. Nie wydaje się więc, aby te wzmianki, chociaż tak ubogie, nie zasługiwały $\mathrm{z}$ wielu względów na odnotowanie $\mathrm{w}$ wydawnictwach dyplomatycznych wśród dokumentów z pełnymi tekstami i wzmiankami o dokumentach okazywanych podczas lustrowania królewszczyzn, gdyż na pewno wyszły $z$ konkretnej kancelarii monarszej i w danym okresie spełniały wyznaczoną im przez wystawcę i określoną w dyspozycji rolę. Nawet sprawa braku datacji nie jest aż takim dużym upośledzeniem „sądowych wzmianek", jakby się mogło wydawać, bo nieodnotowane konkretne daty mieszczą się przecież $w$ latach panowania danego wladcy.

Mając to na uwadze, zbierałem wiadomości z ksiąg sądowych o dokumentach książęcych i królewskich, które w zdecydowanej większości dziś już nie istnieją. W niniejszym artykule dokładniej zajmuję się wzmiankami o dokumentach Kazimierza Wielkiego. Zamieszczonym poniżej wzmiankom daleko do kompletności, sporo $\mathrm{z}$ nich tkwi bowiem $\mathrm{w}$ innych zespołach archiwalnych. Zdecydowalem się jednak na publikacje tego zbiorku $\mathrm{z}$ nadzieją, że zawarte w nim wiadomości mogą być wykorzystane $w$ badaniach nad niektórymi spośród zagadnień wiążących się z dziejami spoleczno-gospodarczymi Malopolski w XIV w.

Wśród odnotowanych w księgach sądowych dokumentów książęcych i królewskich dominują akty informujące o prawie niemieckim i immunitecie sądowym. L. Lysiak w ciekawej i ważnej rozprawie w zwięzły sposób przedstawił problem funkcjonowania małopolskich dokumentów lokacyjnych w praktyce sądowej XIV-XVI w. ${ }^{3} \mathrm{Na}$ opracowanie czeka jednak nadal przebadanie funkcjonowania w tym czasie w praktyce sądowej innych, oprócz aktów lokacyjnych, dokumentów małopolskich.

${ }^{2}$ Por. np. ZDM 1, nr 30, 43, 45, 134; 4, nr 941.

${ }^{3} \mathrm{~L}$. Lysiak, Malopolskie dokumenty lokacyjne w praktyce sqdowej XIV-XVI wieku, CPH 1964 , t. XVI, z. 2, s. $45-67$. 
W księgach sądów ziemskiego, nadwornego i grodzkiego najliczniejsze są wzmianki o dokumentach Kazimierza Wielkiego. Na drugim miejscu jako wystawce trzeba wymienić Władysława Jagiełlę. Niezbyt liczne są natomiast wzmianki o dokumentach Władysława Lokietka, a sporadyczne - o dyplomach Elżbiety Wielkiej i Ludwika Węgierskiego. Równie sporadyczne są wzmianki o okazywanych w sądach dokumentach książęcych. Rozbrajająca jest na przykład informacja pisarza zapiski sądowej o tym, że w 1401 r. Piotrasz z Potoku oddalił roszczenia pozywającego go Jaszka z Potoku o podział dziedziny w Potoku iure prescripcionis per privilegium cuiusdam ducis ${ }^{4}$. Nieznany dziś dokument książęcy, dotyczący wsi Potok koło Jędrzejowa, zapewne został wystawiony w XIII w.

Książę Władysław Lokietek w roku 1317 przeniósł z prawa polskiego na niemieckie imiennie wymienione wsie klasztoru staniąteckiego i nadał klasztorowi immunitet sądowy ${ }^{5}$. Znalazła się w nim także klauzula, według której klasztor mógl bez przeszkód przenosić na prawo niemieckie wsie później nabywane. Tym zachowanym do dziś dokumentem klasztor ten w XV w. wielokrotnie wyjmowal swoich poddanych spod jurysdykcji sądów grodzkiego i ziemskiego. Ciekawy jest tu przykład Kotowic. Do roku 1400 wieś ta była własnością szlachecką. W roku 1388 Mikołaj z Sieradzic dowiódł przed sądem ziemskim, że wieś Kotowice posiada prawo niemieckie, okazując dokument w tej sprawie. Później jej dziedzicem został Jan z Tẹczyna. W $1400 \mathrm{r}$. nabyl ją klasztor w Staniątkach od kasztelana krakowskiego Jana z Tęczyna w zamian za część Gnatowic. W roku 1423 opatka staniątecka posłużyla się jednak nieokazanym w $1388 \mathrm{r}$. dyplomem w sprawie prawa niemieckiego, ale dokumentem Władysława Łokietka z roku 1317, dowodząc, że imiennie wymienione wsie klasztorne, $w$ tym Kotowice, posiadają prawo niemieckie. W książęcym dokumencie wieś ta nie figurowała, gdyż wówczas nie należała do klasztoru. Gdy jednak stała się ona nabytkiem klasztornym, automatycznie została objęta przyznanymi klasztorowi przez Władysława Łokietka przywilejami, w tym możliwością korzystania $\mathrm{z}$ prawa niemieckiego ${ }^{6}$.

Podobny $\mathrm{i}$ ciekawy przykład pochodzi $\mathrm{z}$ tego samego roku 1423. Opat szczyrzycki wyjął spod jurysdykcji grodzkiej swoich kmieci z Abramowic pozwanych przez kmieci Śmiła z Markuszowej, okazał bowiem dokument $\mathrm{z}$ pieczęcią króla Kazimierza $\mathrm{z}$ dokumentem jego ojca Władysława, według którego kmiecie mają być sądzeni wobec braci klasztornych i sołtysów wsi klasztornych, zgodnie $\mathrm{z}$ prawem niemieckim. Opat okazał w sądzie jeden

\footnotetext{
${ }^{4}$ TC 3, s. 232.

${ }^{5} \mathrm{KDP} 3, \mathrm{nr} 76$.

${ }^{6} \mathrm{CC} 2$, s. 205; KDP 3, nr 76; SHG, cz. 3, s. 62.
} 
zachowany dokument Kazimierza $\mathrm{z}$ roku 1333, którym transumowal on dyplom Władysława Lokietka z 1308 r. Książę ten zezwolił klasztorowi lokować wszystkie swoje niewymienione $\mathrm{z}$ nazwy wsie na prawie niemieckim, w tym posiadane przezeń Abramowice?.

W innych przypadkach pisarze nie byli tak skrupulatni, wymieniając tylko wystawcę transumptu, jak w przypadku dyplomu Kazimierza Wielkiego $\mathrm{z}$ roku 1356, którym transumował dokument Bolesława Wstydliwego dla Radwanitów, o czym dokładniej niżej.

Częste niestety byly przypadki odnotowywania tylko tego, że strona procesowa okazała w sądzie dokument prawa niemieckiego przysługującego danej wsi. Chociaż nie wiadomo, kto i kiedy wystawil taki dokument, to nawet te karłowate wzmianki mają ważne znaczenie nie tylko $\mathrm{w}$ badaniach nad szerzeniem się prawa niemieckiego, ale także nad rozwojem osadnictwa. $\mathrm{Na}$ przykład $3 \mathrm{~V} 1386 \mathrm{r}$. pani Spytkowa $\mathrm{z}$ Więckowic okazała w sądzie ziemskim dokument, zgodnie $\mathrm{z}$ którym jej kmiecie winni być sądzeni $\mathrm{w}$ jej dziedzinie wedhug prawa niemieckiego. Dokument ten okazano w sądzie także $w$ roku $1388^{8}$. Wystawca na pewno nie był Wladysław Jagiełlo, a najpewniej Kazimierz Wielki. Takich właśnie ogólnikowych wzmianek o dokumentach lokacyjnych odnotowano sporo w księgach sq̨du wyższego prawa niemieckiego na zamku krakowskim. Korzystał z nich szeroko w swych badaniach L. Lysiak.

Bywało, że strony nie były zorientowane, jakim prawem rządzila się wieś. W roku 1388 Jakub $\mathrm{z}$ Kościelca przysięgą oddalił pozew Mikołaja z Marszowic o dokument dotyczący Łękawy, ponieważ nie wiedzial, czy w tej wsi było prawo niemieckie?. W tym samym roku sołtys $z$ Poręby Dzierżnej Andrzej nie przedłożył w sądzie dokumentu $\mathrm{z}$ prawem niemieckim $\mathrm{w}$ sporze $\mathrm{z}$ opiekunem jego dzieci $\mathrm{z}$ pierwszej żony Jakuszem $\mathrm{z}$ Owczar, dlatego nie zostal wyłączony spod jurysdykcji sądu ziemskiego, który zawyrokowal, że winien odpowiadać przed sądem wiecowym. Dokument ten był jednak w posiadaniu Andrzeja. Nie okazal go zapewne dlatego, że obawiał się jego utraty. W 1389 r. ugodził się bowiem ze swoimi dziećmi w sprawie podziału inwentarza, majątku i posagu ich matki. Gdy dzieci osiągną lata sprawne, Andrzej przekaże dokument prawa niemieckiego Mroczkowi ze Szreniawy i Jakuszowi z Owczar, którzy zdeponują go w jednym miejscu, skąd nie będzie go mogła zabierać jedna strona bez wiedzy drugiej strony. Ponadto Andrzej wyznaczy dzieciom całą karczmę na odprawianie sądów i na inne potrzeby ${ }^{10}$.

\footnotetext{
${ }^{7} \mathrm{KDM} 1$, $\mathrm{nr}$ 140, 193; CC 2, s. 16, 17.

${ }^{8}$ SP 8, nr 4052, 4681.

${ }^{9}$ SP 8, nr 4499 - do Marszowskiego należała wówczas Lekkawa Dalechowice i Łękawa Nagórzany.

${ }^{10} \mathrm{SP} 8, \mathrm{nr} 4876,5211$.
} 
Często dokumenty ginęły. W roku 1398 Iwo z Obichowa i Jedlczy stawił przed sądem sześciu świadków, którzy zeznali: ...jaco $w$ Jedlczi bilo nemeczske prawo, ale sginanl prziuiley ${ }^{11}$. Nierzadko dokumenty lokacyjne trawil pożar. Na przykład w roku 1405 świadkowie ze strony Piotra sołtysa z Paczołtowic zeznali przed sądem ziemskim, że miał on dokument prawa sołeckiego, ale się spalil, a soltys zeznal swoje prawa przed wójtem sądu najwyższego prawa niemieckiego w Krakowie ${ }^{12}$. Solectwo $w$ tej wsi musiało powstać znacznie przed rokiem 1380, skoro już w latach 1380-1386 sołtys z Paczołtowic Święszek był ławnikiem sądu wyższego prawa niemieckiego na zamku krakowskim ${ }^{13}$. Wydaje się, że dokument lokacyjny wystawił Kazimierz Wielki. Przy braku pewności nie zamieszczam wzmianki o nim poniżej w wykazie.

Zdarzało się, że współrodowiec gwałtem zabierał dokument. W roku 1439 Piotr $\mathrm{z}$ Łapanowa herbu Drużyna pozwal Jana Lipskiego z Szyku o zabranie mu między innymi szkatulki $\mathrm{z}$ dokumentami (cum litteris privilegiatis) i innymi rzeczami wartości 100 grzywien ${ }^{14}$.

Kupujący wieś otrzymywal od sprzedającego dotyczące jej dokumenty. W roku 1421, decyzją sądu, Frykacz z Mnikowa do sześciu tygodni winien przedłożyć dokument z prawem niemieckim celem wyjęcia swoich poddanych spod jurysdykcji grodzkiej, zeznał bowiem, że jeszcze nie otrzymał dokumentu od sprzedającego mu wieś Mników ${ }^{15}$. Często dziedzice posiadali więcej dokumentów na swoją wies. W latach 1400-1407 dziedzice w Grodowicach procesowali się między sobą o trzy dokumenty dotyczące tej wsi (pro privilegiis tribus hereditariis). Nic jednak nie wiadomo o ich wystawcach. Świadkowie zeznali, że w posiadaniu Piotra - dziedzica ze Zbilutowic i Grodowic, są trzy dokumenty na Grodowice. Piotr potwierdził to, ale co do dwóch dyplomów na tę dziedzinę. Zeznal też, że również powódka Małgorzata z Grodowic może wraz $\mathrm{z}$ nim bez przeszkód $\mathrm{z}$ nich korzystać. Są one $w$ jego posiadaniu i zostaną zdeponowane $w$ skarbcu ${ }^{16}$. Wystawcą jednego przynajmniej dokumentu mógł być Kazimierz Wielki.

Ciekawe wiadomości odnoszą się do wsi Wronin i Wroniniec. W tych wsiach współdziedziczyli szpital św. Krzyża w Krakowie reprezentowany na przełomie XIV/XV w. przez przełożonego (magister) Wita i Imram Starszy z Czulic. W 1400 r. toczyli oni spór między sobą. Magister Wit okazał w sądzie ziemskim dokument księcia krakowskiego Władysława w sprawie prawa niemieckiego nadanego dwom wsiom Wronin. Wyjął zatem swoich kmieci spod jurysdykcji tego sądu. Wit dysponował zachowanym do dziś

\footnotetext{
${ }^{11}$ SP 8, nr 6750, 6772, 6775, 6780; SHG, cz. 2, s. 287.

${ }_{12}$ TC 3 b, s. 510 .

${ }^{13} \mathrm{KDM} 1$, nr 360, 362; Kodeks dyplomatyczny wielicki, Lwów 1872, s. 10.

14 CC 6, s. 299.

${ }^{15}$ CC 1, s. 454 - zapiskę później skreślono, Frykacz okazał więc dokument prawa niemieckiego.

${ }^{16}$ CC 1b, s. 38, 39, 98, 100; Kartoteka Pracowni.
} 
i wydanym dyplomem Wladysława Lokietka wystawionym w roku 1309 dla wspomnianego szpitala. Posłużył się nim również magister Mikołaj w $1415 \mathrm{r}$. w sporze z Zakliką z Birkowa w sprawie główszczyzny za swego poddanego ${ }^{17}$. W roku 1407 Imram z Czulic $w$ toku procesu swoich kmieci z Wronińca z Wawrzyńcem z Janowic okazal dokument księcia krakowskiego Leszka (Lesconis), wyjmując swoich kmieci spod jurysdykcji grodzkiej. Starosta krakowski potwierdził Imramowi jego prawa sądownicze, uczyni więc Wawrzyńcowi sprawiedliwość $w$ swojej dziedzinie, czyli we Wronińcu ${ }^{18}$. Dokument księcia Leszka nie zachowal się. Wystawił go zapewne Leszek Czarny. Imram $z$ Czulic posiadał $w$ tej wsi już niezbyt wielką część. Nie wspomniano o prawie niemieckim, co wskazuje, że książę nadał przodkowi Imrama immunitet sądowy. Z Wronińcem wiąże się jeszcze jeden ciekawy dokument. W 1413 r. Stanisław Wiewiórka z Wronińca, naganiony przez Mikołaja Wałacha z Wronińca, oczyścił swoje szlachectwo i herb Stary Koń, okazując w sądzie dokument pergaminowy domini Wladislai Loketk olim regis Polonie, który nie zachowal się do naszych czasów ${ }^{19}$.

W 1407 r. Piotrasz z Uliny wyjął swych dwóch kmieci spod sądownictwa grodzkiego w sporze $\mathrm{z}$ Klemensem $\mathrm{z}$ Uliny, okazując dokument króla polskiego Władysława, według którego Piotrasz i jego poddani w trzech wsiach o nazwie Ulina korzystają z prawa niemieckiego. Każdy poddany będzie odpowiadał przed Piotraszem, a on przed królem albo na wiecu generalnym. Piotrasz przedstawil najpewniej dokument Wladysława Lokietka $\mathrm{z}$ lat 1320-1333, ponieważ już w roku 1382 została poświadczona Ulina Mała, a w $1376 \mathrm{r}$. było już zbyt wielu dziedziców Uliny, aby ich wszystkich razem dotyczył jeden dokument wystawiony dopiero przez Wladysława Jagiełlę ${ }^{20}$. Duże rozdrobnienie wlasności $w$ końcu XIV w. dowodzi, że lokacja na prawie niemieckim nastąpiła znacznie wcześniej, gdy nie było aż tylu właścicieli. W roku 1402 Piotrasz z Uliny zastawił Piotraszowi i jego matce Mściwoi - dziedzicom z Polekarcic - $61 / 2$ lanu w Ulinie i lasek zwany Dobkowski $\mathrm{z}$ wszystkimi uprawnieniami excepto iure scolteti et scoltecie ibidem ${ }^{21}$.

W 1423 r. na roczkach w Proszowicach Jan - syn Stanisława z Ilkowic, $\mathrm{w}$ sporze $\mathrm{z}$ Jakuszem $\mathrm{z}$ Janowic per privilegium domini Wladislai antiqui regis Polonie homines et kmetones suos de Janouice a iurisdictione terrestris exhibuit in quo priuilegio clare contineret, quod dicti homines et kmetones sui de Janouice nullas nisi in hereditate ibidem in iure teutonico cuilibet querulanti contra ipsos habent respondere. Et sic circa tenorem dicti privilegii est iuridice conservatus ${ }^{22}$. Dokument ten dziś już nie istnieje.

\footnotetext{
${ }^{17} \mathrm{KDM} 1$, nr 141; SP 8, nr 9745; SP 2, nr 1384.

${ }^{18} \mathrm{CC} 1 \mathrm{~b}$, s. 111.

${ }^{19} \mathrm{SP} 2, \mathrm{nr} 1313$.

${ }^{20}$ CC 1b, s. 122; SP 8, nr 140 i n., 1894; Kartoteka Pracowni.

${ }^{21}$ SP 2, nr 859.

22 TC 195 , s. $196,357,358$.
} 
$\mathrm{Na}$ pożytek dyplomatyki warto zasygnalizować sprawę dokumentu lokacyjnego wsi Kąśnej. W 1404 r. Wiernek z Kąśnej okazał w sądzie dokument $\mathrm{z}$ prawem magdeburskim wystawiony przez króla Kazimierza, a sąd zachował go przy jego prawach. Dokument lokacyjny tej wsi wydal S. Kuraś z kopii z roku $1761^{23}$. Wystawił go Kazimierz Wielki w roku 1344, powierzając Jakubowi - synowi Racława, osadzenie na prawie magdeburskim wsi o nazwie Kąśna po obu brzegach rzeki Kąśnianki. Generalnie dokument nie różni się niczym od innych aktów lokacyjnych tego wystawcy. Wydawca poprawił błędy kopisty, w tym datę z 1314 na 1344 r., z którą pozostaje $w$ zgodzie lista świadków. Zaznaczył równocześnie interpolację, którą tekst dokumentu zostal skażony, a dotyczącą mesznego po ćwierci z łanu w życie i owsie dla plebana (w Jastrzębiej) oraz po kwarcie dla kościelnego. W roku 1387 Władysław Jagiełło za zasługi nadal Piotrowi Rożnowi z Rożnowa herbu Gryf wsie Kąśną, Jastrzębię i Paleśnicę ${ }^{24}$. Piotrowi został między innymi przekazany dokument lokacyjny Kąśnej z datą 1344. Po jego śmierci wdowa po nim wyszła za mąż za Wiernka z Gabania, który zarządzał jej i jej dzieci majątkiem. $Z$ tego powodu pisał się z Rożnowa i Kąśnej, mógł też dysponować dokumentem Kazimierza Wielkiego w sprawie lokacji Kąśnej. Wieś ta rządziła się prawem niemieckim, gdyż w 1455 r. zostali poświadczeni podwójci i lawnicy. Mimo to w roku 1472 Kazimierz Jagiellończyk nadał prawo niemieckie między innymi wsi Kąśnej należącej do braci Eleazara, Jana, Mikołaja i Zygmunta, którzy przecież byli potomkami Piotra Rożna ${ }^{25}$. W latach 1404 i 1761 przedkładano na rokach w Czchowie i w grodzie bieckim zapewne ten sam dokument $\mathrm{z}$ prawem magdeburskim, który po roku 1404, a najpewniej dopiero około polowy XVIII w., został interpolowany. W roku $1760 \mathrm{w}$ grodzie krakowskim przedstawiono do oblaty wystawiony przez Kazimierza Wielkiego dokument lokacyjny dla wsi Liszki $\mathrm{z}$ datą $1366^{26}$. Tekst tego dokumentu znajdowal się $\mathrm{w}$ wyciągu $\mathrm{z}$ aktów oficjalatu krakowskiego. Dyplom lisiecki jest falsyfikatem, sporządzonym na użytek tamtejszego plebana na podstawie dokumentu dla Kąśnej, który wówczas był już skażony interpolacją i zawierał błędy, powtórzone nad wyraz skrupulatnie w tym falsyfikacie ${ }^{27}$.

W 1451 r. Mikołaj Damicki z Damic wziąl za 120 grzywien w dzierżawę na cztery lata wieś Szyce od Hanka z Chełmu - prebendarza od św. Marcina w Krakowie. Damicki jeszcze tego roku uwolnil kmiecia z Szyc spod jurysdykcji ziemskiej, gdyż wieś rządzila się prawem niemieckim. Okazał w sądzie dokument

\footnotetext{
${ }^{23}$ TCz. 1, s. 152; ZDM 1, nr 44.

${ }^{24} \mathrm{ZDM} 8$, nr 2540, 2542b.

${ }^{25}$ SHG, cz. 2, s. 471,472 .

${ }^{26} \mathrm{ZDM} 1$, nr 118.

${ }^{27}$ F. Si k o r a, Dokumenty tynieckie Kazimierza Wielkiego, Zap. Hist. 1985, t. L, z. 3, s. 167-169; SHG, cz. 3, s. 680-682. Por. też teksty dyplomów w ZDM 1, nr 44 i 118.
} 
na Szyce opatrzony pieczęcią księcia krakowskiego Leszka ${ }^{28}$. Damicki wziął zatem $\mathrm{w}$ dzierżawę wieś wraz $\mathrm{z}$ ważnym i aż tak dawnym dokumentem książęcym, który później zaginąl. Zauważyć przy tym wypadnie, że pierwsze bezpośrednie wiadomości o Szycach poczynają się dopiero w $1400 \mathrm{r}^{29}$ Okazany natomiast $w$ sądzie $w$ roku 1451 dokument dowodzi, że wieś ta najpóźniej przed 1288 r., o ile wystawcą był Leszek Czarny albo jako już istniejąca, uzyskała możliwość korzystania z prawa niemieckiego, albo dopiero wtedy rozpoczął się proces jej lokacji na tym prawie.

W roku 1440 mieszczanie z Mstowa okazali w sądzie grodzkim litteram privilegialem, quod non debent hic iudicari in castellania sed in iure suo privilegiato. Pisarz nie podal imienia wystawcy dokumentu, nie mówiąc o dacie. Mógl to być dokument lokacyjny miasta wystawiony w 1278 r. przez Bolesława Wstydliwego, albo potwierdzający miastu prawo niemieckie dyplom Władysława Jagielly $\mathrm{z}$ roku 1405 - również z formułą immunitetu sądowego. Królowi klasztor mstowski okazal litteras privilegiales, w tym fundationem oppidi Mstouiensis ${ }^{30}$.

Wieś Kościelniki koło Krakowa rządziła się prawem niemieckim. W XIV w. należała do Gutów herbu Rawa. Pod koniec tego wieku, najpóźniej przed rokiem 1384, jej połowa przez małżeństwo znalazła się w rękach Straszów herbu Odrowąż. W 1420 r. sąd ziemski odłożył na inny termin decyzję w sprawie dokumentu z prawem niemieckim, o który spierali się dziedzice swych części w Kościelnikach. Do tego czasu Elżbieta Straszowa i jej dzieci winni okazywać ten dokument Gutom w każdej potrzebie ${ }^{31}$. Po roku 1384 nie było możliwości przeprowadzenia lokacji dwóch części i do tego mocno skłóconych już ze sobą dziedziców na podstawie jednego aktu królewskiego, a później - kontraktu dla soltysa. Wynika z tego, że najpóźniej Kazimierz Wielki udzielił dziedzicowi zezwolenia na lokację tej wsi na prawie niemieckim.

Przytoczone powyżej przykłady dokumentów książęcych i królewskich w praktyce sądowej $w X V$ w. ilustrują możliwości badawcze i w pełni uzasadniają postulat podjęcia tych badan. Nie wspominałem tu o wzmiankach o zaginionych dokumentach Władyslawa Jagiełly, ponieważ zamierzam omówić je w osobnym artykule.

W zapiskach sądowych zdecydowanie przeważają wamianki o dokumentach dotyczących prawa niemieckiego. W wyjątkowo bogatym i cennym dorobku naukowym Profesora Józefa Matuszewskiego poczesne miejsce zajmują książki, artykuly i rozprawy poświęcone różnym aspektom tego prawa. Swój pogląd na jego znaczenie wyraził Profesor w zwięzły sposób nawet w tytule jednego

${ }^{28}$ TC 14, s. $18,19,61$.

${ }^{29}$ SP 8, uwaga 336/36, 338/23, 340/42.

${ }^{30} \mathrm{KDM} 2$, nr 485; ZDM 6, nr 1674; CC 7, s. 151.

${ }^{31}$ TC 7, s. 43, 44; SHG, cz. 2, s. 40-44. 
ze swoich artykułów: Ius Teutonicum. Średniowieczna reforma rolna w Polsce ${ }^{32}$. Reforma ta nabrała wyjątkowego rozmachu za panowania Kazimierza Wielkiego, który nie tylko wprowadzal to prawo do dóbr porządkowanej domeny monarszej, powiększając ją o nader licznie zakładane nowe wsie na prawie niemieckim, ale również obficie obdarzał tym prawem posiadłości rycerskie i kościelne. W przypadku Małopolski najlepiej ilustrują to wydane przez I. Sulkowską-Kuraś i S. Kurasia bardzo liczne dokumenty lokacyjne wystawione przez tego monarchę.

W pracach poświęconych szerzeniu się prawa niemieckiego dużą wagę przykłada się do liczbowych zestawień, które, choć są tylko orientacyjne $\mathrm{z}$ powodu mimo wszystko niskiej liczby zachowanych do naszych czasów średniowiecznych dokumentów, to jednak generalnie potwierdzają pogląd o szczególnie intensywnej kolonizacji na prawie niemieckim $\mathrm{w}$ XIV $\mathrm{w}^{33}$ Według ustaleń J. Lucińskiego w odniesieniu do domeny monarszej w Małopolsce szczególnego rozmachu nabrała akcja kolonizacyjna z lat 1340-1370. Te doniosłe przemiany dostrzegali już współcześni, co znalazło odbicie w kronice Janka $\mathrm{z}$ Czarnkowa ${ }^{34}$. Jeśli zatem do wykazów liczbowych J. Lucińskiego doda się opublikowane później dokumenty lokacyjne Kazimierza Wielkiego dla dóbr monarszych w Zbiorze dokumentów malopolskich, a ponadto wzmianki o zaginionych jego dyplomach dla wsi z terenu ziemi krakowskiej, to słuszność owych ustaleń nie może podlegać dyskusji. Zauważyć tu trzeba, że J. Luciński wykorzystał skrupulatnie wzmianki o zaginionych dokumentach tego króla przytoczone w lustracjach dóbr monarszych. Zebrane przezeń dane co do dóbr monarszych sprzed 1333 r. uzupełniają także niektóre ze wspomnianych wyżej przykładowo wzmianek. Ważnym jednak uzupełnieniem badań nad lokacjami miast i wsi monarszych do roku 1385 byłoby wykorzystanie owych karłowatych wzmianek o dokumentach lokacyjnych z ksiąg sądowych, ale postulat ten byłby wyjątkowo trudny i żmudny do zrealizowania. Nie wystarczałoby tu samo ich odszukanie. Konieczna byłaby także próba ustalenia, czy lokacja miała miejsce przed rokiem 1385, czy po tym roku.

W poniższym zestawieniu ograniczyłem się do wzmianek o zaginionych dokumentach Kazimierza Wielkiego dotyczących nie tylko prawa niemieckiego. Sporo jest wśród nich aktów wystawionych dla rycerzy, nawet posiadających

${ }^{32} \mathrm{~W}$ : Zagadnienia prawa konstytucyjnego. Ksiega pamiqtkowa ku czci Profesora Tadeusza Szymczaka, Łódź 1994, s. 224-245.

${ }^{33}$ Np. A. G ą sior row ski, Ze studiów nad szerzeniem sie tzw. Prawa niemieckiego we wsiach ziemi krakowskiej i sandomierskiej (do roku 1333), RH 1960, 26, s. 123-170; S. K u raś, Przywileje prawa niemieckiego miast $i$ wsi malopolskich XIV-XV wieku, Wrocław 1971; J. Luciński, Lokacje miast $i$ wsi monarszych w Malopolsce do roku 1385, CPH 1965, t. XVII, z. 2, s. 93-122; S. Pła za, Solectwa w powiecie sqdecko-czchowskim w XIII-XVIII w., Rocz. Sądecki 1963, t. 9, s. 7-148.

${ }^{34}$ J. Lu ciński, Lokacje..., s. 109. 
niezbyt rozległe dobra. Na pierwszym miejscu wymienić należy akty z zezwoleniem na używanie w ich dobrach prawa niemieckiego przez ich poddanych, na drugim - dyplomy $\mathrm{z}$ udzielonym rycerzom immunitetem sądowym, bez informacji o zezwoleniu na używanie prawa niemieckiego, na trzecim - potwierdzenia różnych czynności prawnych, nawet drobnych. Wzmianki dostarczają też danych o relacjach pomiędzy monarchą a poddanymi. Potwierdzają przede wszystkim słuszność stanowiska L. Lysiaka, który zakwestionował tezę, jakoby kolonizacja na prawie niemieckim byla wyłączną domeną wielkiej własności ziemskiej. Zauważyl on przy tym, że lokacją na tym prawie objęte były na pewno wsie należące do średniej szlachty i to już w XIV w., co da się stwierdzić w konkretnych wypadkach ${ }^{35}$. W poniższym wykazie zdecydowanie przeważaja dokumenty związane z sądownictwem. Nie bez powodu bowiem L. Lysiak mocno podkreślal wszechstronną rolę dokumentów lokacyjnych przejawiającą się tam, gdzie chodzilo o ustalenie właściwości sądu. Często na ich podstawie dokonywano remisji spraw chłopskich do odpowiednich sądów wiejskich, odcinając tym samym ludność chłopską od innych instancji feudalnego wymiaru sprawiedliwości, na co zwracał uwage J. Matuszewsk ${ }^{36}$. Pewna grupa wzmianek o zaginionych dokumentach dotyczy remisji spraw szlacheckich $\mathrm{z}$ sądów grodzkiego i ziemskiego do przysługujących im sądów nadwornego i wiecowego. W kilku przypadkach szlachcice $\mathrm{z}$ ziemi sądeckiej dokumentami Kazimierza Wielkiego $\mathrm{z}$ immunitetem sądowym wykazywali, że dla nich niewłaściwym był sąd sprawowany przez kasztelana sądeckiego, który w tej ziemi wyjątkowo sprawowal także sądownictwo ziemskie.

W poniższym wykazie nie uwzględniałem tych wzmianek o dokumentach Kazimierza Wielkiego, które informowały tylko o poleceniu sądu okazania przez stronę dokumentu, a nie udało się ustalić, czy miało to miejsce. Zrezygnowałem też $\mathrm{z}$ tych licznych wzmianek o dyplomach, zwłaszcza lokacyjnych, bez danych o ich wystawcach, wśród których na pewno dominował Kazimierz Wielki, i po analizie zachowanych źródeł można było na niego wskazać nieraz prawie z pewnością lub z pewnym prawdopodobieństwem. Ponieważ moje uwagi dotyczą wyłącznie wzmianek o zaginionych dokumentach, dlatego pominąłem dane o pojawiających się jeszcze tu i ówdzie niewydanych dokumentach tego króla. Wspomnieć tu można o wręcz ciekawostce. W Bibliotece Jagiellońskiej w Krakowie znajduje się, opatrzony sygnaturą 8, oryginał niewydanego dyplomu Kazimierza Wielkiego wystawionego w Krakowie 11 XI 1333 r. dla Żydów krakowskich, którym sześciu ich rzeźnikom przyznał prawo sprzedaży mięsa w mieście. Oryginal ten był tam nie tylko w czasach F. Piekosińskiego, ale również i później, a wydała go dopiero B. Wyrozumska. Z kolei w kolekcji Tomasza

${ }^{35}$ L. Łysiak, Malopolskie dokumenty lokacyjne..., s. 47, 50, 51.

${ }^{36}$ Ibidem, s. 63; J. Matuszewski, W sprawie genezy sqdu referendarskiego, CPH 1954, t. VI, z. 2, s. 435. Zob. też S. Ku raś, Przywileje prawa niemieckiego..., s. 118-143. 
Niewodniczańskiego są też oryginalne dokumenty tego króla, znane dotąd z regestów ${ }^{37}$.

Kilkanaście wzmianek ma ważne znaczenie dla badań nad rozwojem osadnictwa. Przesuwają istnienie danej wsi znacznie wstecz w porównaniu z pierwszymi zachowanymi zapisami ich nazw. O ciekawym przypadku z Szycami wspomnialem wyżej.

Jeśli chodzi o wzmianki o dokumentach Kazimierza Wielkiego można dla przykładu w tym miejscu zwrócić uwagę na wieś Kasinę Wielką, która została odnotowana w zachowanych źródłach w 1398 r., a poświadczał jej istnienie zaginiony dokument tego króla wystawiony najpóźniej w roku 1370 . Cenne są wzmianki o dokumentach lokacyjnych króla dla dóbr szlacheckich, zwłaszcza tych mniejszych. O ile bowiem zachowało się sporo dokumentów ilustrujących kolonizacje na prawie niemieckim w dobrach kościelnych i królewskich, to nie można tego powiedzieć o wsiach i miastach szlacheckich. Wcześniejszy zanik solectw w tych dobrach oraz pochlonięcie ich przez wlasność ziemska spowodowalo, iż dokument lokacyjny rychlo utracil swoje znaczenie, a tym samym odpadla potrzeba jego dalszego zabezpieczenia $i$ troskliwego przechowywania. Nie byl w tym bowiem zainteresowany ani ostatni posiadacz solectwa oraz jego spadkobiercy, ani też wlaściciel ziemski, który drogq skupu przejal uposażenie swojego soltysa $i$ zlqczyl je $z$ wlasnym majatkiem ${ }^{38}$. Zebrane wzmianki wyselekcjonowano z licznych wzmianek w księgach sądowych o tych dokumentach Kazimierza Wielkiego, które zachowały się do dziś i zostały wydane. Okazywane były one w sądach nieraz wielokrotnie. Niewątpliwie naczelne miejsce zajmuje tu dokument Kazimierza Wielkiego $\mathrm{z}$ roku 1366 dla rodu Toporów i Starych Koni. Na przykład w 1420 r. okazal go Żegota z Grzegorzowic, w 1423 r. - Sieciej z Morawicy i Cholerzyna, w 1478 r. - Franciszek Gliwicz ${ }^{39}$. Przypadki powoływania się na ten dokument rejestruje $\mathrm{J}$. Kurtyka ${ }^{40}$. Tego rodzaju grupa dokumentów będzie odgrywać ważną rolę w postulowanych badaniach nad dokumentami monarszymi w praktyce sądowej w Małopolsce.

Osobno wypadnie omówić sprawę wsi Kopytówki w enklawie Radwanitów, wydzielonej z terytorium księstwa oświęcimskiego. W $1426 \mathrm{r}$. prepozyt klasztoru Bożego Ciała na Kazimierzu Jan pozwał do sądu grodzkiego Mikołaja i Marcina - kmieci z Kopytówki, o 40 grzywien (od każdego 20 grzywien) szkody z powodu spalenia mu karczmy w Swoszowicach przy wielkiej drodze. W następnym terminie sąd nakazał kmieciom okazać dokument, że nie

${ }^{37}$ Nieznany dokument Kazimierza Wielkiego, oprac. B. W y rozu mska, Krakowski Roczn. Archiwalny 2004, t. 10, s. 191-195; Katalog dokumentów pergaminowych ze zbiorów Tomasza Niewodniczańskiego $w$ Bitburgu, oprac. J. Tomaszewicz i M. Zdanek, pod red. W. Buk owskie go, Kraków 2004, nr 6, 7, 9.

${ }^{38}$ L. Ly siak, Malopolskie dokumenty lokacyjne..., s. 50.

${ }^{39}$ KDM 1, nr 288; TC 195, s. 82; CC 2, s. 100; 20, s. 723.

${ }^{40} \mathrm{~J}$. K u r l y k a, Tęzyńscy. Studium z dziejów polskiej elity możnowladczej $w$ średniowieczu, Kraków 1997, s. 173. 
powinni stawać $w$ tym sądzie o pożoge $e^{41}$. Na kolejnej rozprawie Filip z Brzezinki excepit et exemit swoich kmieci z Kopytówki dokumentem, quod non debent ipsos et quoslibet alios quilibet palatini et castellani ac quilibet alii dignitarii iudicare ${ }^{42}$. Filip z Brzezinki i Kopytówki herbu Radwan na pewno posiadał $w$ tym czasie dokument Kazimierza Wielkiego z 1356 r., którym król na prośbę Janusza, zwanego Radwanczewic, dziedzica Trzebola transumowal i zatwierdzil dokument Bolesława Wstydliwego z roku 1274. Książę ten, nadając księciu oświęcimskiemu Władyslawowi wsie nad rzeką Skawą na terenie księstwa oświęcimskiego, wyłączył spod jego władzy wsie o nazwie Trzebol należące do zasłużonych rycerzy Radwanitów, pozostawiając je jako enklawę ziemi krakowskiej i swego księstwa. Między innymi zezwolił dwom braciom Radwanitom zakładać w Czarnym Lesie wsie na prawie niemieckim lub polskim $\mathrm{z}$ wszystkimi prawami ${ }^{43}$. Z uwagi na zacytowany fragment zapiski sądowej sformułowanej na podstawie okazanego przez Filipa dokumentu króla Kazimierza można by sądzić, że był to jakiś inny dokument tego władcy, a dotyczył on zezwolenia na przeniesienie Kopytówki na prawo niemieckie. Wydaje się jednak słuszniejszym wnioskowanie o powołaniu się na transumpt królewski z roku $1356 \mathrm{z}$ dokumentem Bolesława Wstydliwego, w którym jest mowa o prawie niemieckim $\mathrm{z}$ wszystkimi prawami, a więc i z nieobjaśnionym szczegółowo immunitetem sądowym. W tej sytuacji pisarz grodzki włączyłby do zapiski sądowej sformułowanie, które stosował, redagując zapiski o wyjęciu strony na przykład spod jurysdykcji grodzkiej, po okazaniu dokumentów lokacyjnych $\mathrm{z}$ immunitetem sądowym zawierających zwolnienie od sądownictwa wojewodów, kasztelanów i innych dygnitarzy. Ten wniosek wspiera fakt wystąpienia w roku 1428 Filipa Radwana z Brzezinki i jego wspólbraci Radwanów z prośbą do Wladysława Jagiełly o transumowanie i potwierdzenie transumptu Kazimierza Wielkiego z $1356 \mathrm{r}^{44}$ Kopytówka została zatem założona na prawie niemieckim w Czarnym Lesie po $1274 \mathrm{r}$.

Wymienianych we wzmiankach miejscowości nie objaśniam dokładniej, ponieważ generalnie ich położenie wskazuje już sam tytuł rozprawy. Ponumerowane wzmianki rozpoczyna data faktyczna lub przybliżona $i$ regest dokumentu oddający jego treść na tyle, na ile na to pozwala treść wzmianki. Jak już wspominałem, wzmianki z reguły nie mają dat rocznych. Te, które posiadają konkretne i w miarę uściślone daty, zostały ułożone według nich. Większość wzmianek pozostała jednak bez możliwości uściślenia daty. Te wzmianki dla uproszczenia opatrzono umowną datą: przed 1370, zamiast 1333-1370, a uszeregowano je alfabetycznie według nazwy miejscowości,

${ }^{41}$ CC 2, s. $537,547$.

${ }^{42}$ CC 2, s. 583.

${ }^{43} \mathrm{KDP} 1$, nr 59 z datą 1278, którą poprawił na rok $1274 \mathrm{O}$. H a lecki, Powolanie księcia Wladyslawa Opolskiego na tron krakowski w r. 1273, KH 1913, 27, s. 283-315; KDP 3, nr 55.

${ }^{44} \mathrm{KDP} 3$, nr 55; SHG, cz. 1, s. 248; cz. 2, s. 271, 761. 
która pełni tu nieformalną rolę pomijanego we wzmiance odbiorcy. Po regestrze podaję treść wzmianki (Wzm.) w opatrzonej datą roczną zapisce sądowej, w której powołano dany dokument, i sygnaturę źródłową. Nierzadko przytaczam fragment tej zapiski, ponieważ został zaczerpnięty przez pisarza sądowego bezpośrednio z okazanego w sądzie dokumentu królewskiego. $\mathrm{Na}$ trzecim miejscu zamieszczam uwage (Uw.), czasem nawet dosyć obszerną, w której wskazuję przypuszczalnego formalnego odbiorcę dokumentu królewskiego. W niektórych uwagach uwzględniam wiadomości wiążące się $z$ treścią zapiski ze wzmianką. Sporo miejsca poświęcono na przyklad wzmiankom o dokumentach dotyczących Karwina, okazywanych w sądach w trakcie sporów pomiędzy dziedzicami $\mathrm{i}$ ich poddanymi.

W poniższym wykazie stosuję następujące skróty:

\begin{tabular}{|c|c|}
\hline GAD & - Archiwum Glówne Akt Dawnych w Warszawie. \\
\hline PK & - Archiwum Państwowe w Krakowie. \\
\hline SK & - Archiwum Skarbu Koronnego, AGAD. \\
\hline CB & $\begin{array}{l}\text { - Acta castrensia Biecensia. Księgi grodzkie bieckie, właściwie księgi bieckiego } \\
\text { sądu leńskiego w APK. }\end{array}$ \\
\hline $\mathrm{CC}$ & - Acta castrensia Cracoviensia. Księgi grodzkie krakowskie w APK. \\
\hline $\begin{array}{l}\text { assiorowski, } \\
\text { Itinerarium }\end{array}$ & $\begin{array}{l}\text { - A. Gą si or ow ski, Itinerarium króla Kazimierza Wielkiego. Materialy } \\
\text { 1333-1370, Roczniki Historyczne 1998, 64, s. 175-208. }\end{array}$ \\
\hline $\begin{array}{l}\text { Kartoteka } \\
\text { Pracowni }\end{array}$ & $\begin{array}{l}\text { - Kartoteka Pracowni Slownika Historyczno-Geograficznego Malopolski w śred- } \\
\text { niowieczu w Krakowie. }\end{array}$ \\
\hline KDM & $\begin{array}{l}\text { - Kodeks dyplomatyczny Malopolski, wyd. F. Piekosiński, t. 1-4, Kraków } \\
\text { 1876-1905. }\end{array}$ \\
\hline KDK & $\begin{array}{l}\text { - Kodeks dyplomatyczny katedry krakowskiej Św. Waclawa, wyd. F. Piekosiński, } \\
\text { Kraków 1874-1883. }\end{array}$ \\
\hline KDP & - Kodeks dyplomatyczny Polski, t. 3, wyd. J. Bartoszewicz, Warszawa 1858. \\
\hline KDT & $\begin{array}{l}\text { - Kodeks dyplomatyczny klasztoru tynieckiego, wyd. S. Kętrzyński i S. Smolka, } \\
\text { Lwów } 1875 \text {. }\end{array}$ \\
\hline KSN & $\begin{array}{l}\text { - Najstarsza ksiega sqdu najwyższego prawa niemieckiego na zamku krakowskim, } \\
\text { wyd. A. Kłodziński, Kraków } 1936 .\end{array}$ \\
\hline SHG & $\begin{array}{l}\text { - Slownik historyczno-geograficzny województwa krakowskiego w średniowieczu, } \\
\text { cz. 1-4, Wrocław-Kraków 1980-2002. }\end{array}$ \\
\hline SP 2 & $\begin{array}{l}\text { - Starodawne Prawa Polskiego Pomniki (wypisy) z ksiag dawnych sqdowych } \\
\text { ziemskich i grodzkich ziemi krakowskiej, wyd. A. Z. Helcel, Kraków } 1870 .\end{array}$ \\
\hline SP 7 & $\begin{array}{l}\text { - Starodawne Prawa Polskiego Pomniki. Inscriptiones clenodiales ex libris } \\
\text { iudicialibus palatinatus Cracoviensis. Zapiski herbowe krakowskie, wyd. } \\
\text { B. Ulanowski, Kraków } 1885 \text {. }\end{array}$ \\
\hline SP 8 & $\begin{array}{l}\text { - Starodawne Prawa Polskiego Pomniki. Antiquissimi libri iudicales terre } \\
\text { Cracoviensis, ed. B. Ulanowski, Kraków 1885. }\end{array}$ \\
\hline TB & - Acta terrestria Biecensia. Księgi ziemskie bieckie w APK. \\
\hline TC & - Acta terrestria Cracoviensia. Księgi ziemskie krakowskie w APK. \\
\hline TCz. & - Acta terrestria Czchoviensia, Ksiegi ziemskie czchowskie w APK. \\
\hline & $\begin{array}{l}\text { Zbiór dokumentów malopolskich, wyd. S. Kuraś, I. } \\
\text { Kraków-Wrocław 1962-1975. }\end{array}$ \\
\hline
\end{tabular}


1. Po 1345 r. przed 1370 r. król zatwierdza rozporządzenie w sprawie dóbr Leśniów i Zielenice pozostałych po Piotrze Ziai.

Wzm. z 1399 r.: Dorota, wdowa po Mikolaju z Grodziny, okazując w sądzie ziemskim dok. Kazimierza W., pozyskała na Jaszku i Stanisławie z Lawszowa $1 / 4$ dziedzin $w$ Leśniowie i Zielenicach pod warunkiem, ze wykupi za własne pieniądze z zastawu czesść w Zielenicach. Bracia dokonuja z siostrą podziału Leśniowa (SP 8, nr 8189).

Uw. Piotr Ziaja zmarl przed $1345 \mathrm{r}$. W tym bowiem roku Kazimierz W. poświadczal, że szlachetna Agnieszka - córka zmarłego Piotra zw. Ziaja, sprzedała Hankowi Romańcowi - mieszczaninowi krakowskiemu za 170 grzywien praskich, szatę scarletica dla siebie i inną boxornica dla męża folwark w sąsiedztwie kościoła św. Mikołaja przed Krakowem, który ma $\mathrm{z}$ zamiany $\mathrm{z}$ mężem Andrzejem za dziedzinę po matce jako posag $\mathrm{zW}$. Ządów (KDM 1, nr 219).

2. W 1354 r. król sprzedaje za 44 grzywny solectwo w Siedlcu i określa uposażenie soltysa.

Wzm. z 1631 r.: okazano sporządzającym inwentarz starostwa olsztyńskiego pergaminowy dok. króla Zygmunta z 1569 r., który na sejmie w Lublinie transumowal dok. Kazimierza W. wystawiony w Częstochowie w $1354 \mathrm{r}$. w sprawie sprzedaży sołectwa za 44 grzywien i uposażenia sołtysa. Należą do niego trzy łany, dwa ogrody, trzeci denar z każdej sądzonej sprawy. W zamian za młyn sołtys dostaje 60 wolnych barci w lasach. Kmiecie, którzy będą mleć w tym młynie, obowiązani płacić królowi po wiardunku, a sołtysowi tytułem czynszu młyńskiego - również po wiardunku. Będą odrabiać dwa dni pańszczyzny, a trzeci dzień na pisemną prośbę (tenutariusza). $Z$ każdego łanu obowiązani dawać na Wielkanoc po jednym i na Wniebowzięcie NMPanny po dwa kurczęta, wykonywać vectiones omnes alias przewozy, dawać dwa obiady w roku sędziemu królewskiemu, a trzeci będzie dawać sołtys, który na wyprawę wojenną ma się stawić w zbroi i na koniu wartości 3 grzywien. Sołtys uzyskuje prawo korzystania z lasu Grodzisko na swoje potrzeby i cele budowlane. Król udziela immunitetu sądowego (AGAD, ASK XLVI 42, k. 92 - inwentarz starostwa olsztyńskiego z 1631 r., wg odpisu J. Laberscheka).

3. W 1355 r. król zezwala (Piotrowi ze Szczekocin) na założenie na prawie niemieckim miasta $w$ jego wsi Szczekociny.

Wzm. z 1506 r.: Katarzyna - wdowa po Wojciechu ze Szczekocin, przekazała w sądzie ziemskim Jakubowi z Dębna i Sprowy, stryjowi i opiekunowi dzieci jej i zmarłego Wojciecha, pięć dok. w sprawie Szczekocin i królewskiej wsi Małyszyce, którą Szczekoccy mieli w tenucie od XIV w. Jako pierwszy zostal wymieniony zaginiony dok. w sprawie lokacji miasta, a jako drugi-zachowany do dziś dok. tego króla z 1341 r. na sołectwo w Małyszycach, opublikowany przez S. Kurasia (TC 312, s. 256, 257; ZDM 1, nr 41). 
Uw. Odbiorcą dok. Kazimierza W. był Piotr ze Szczekocin - późniejszy kasztelan sądecki (1368-1374), a następnie lubelski (1375-1384), do którego należały wówczas Szczekociny (Urzędnicy Malopolscy XII-XV wieku. Spisy, Wroclaw 1991, s. 366).

4. W 1356 r. król powierza Janowi zw. Stola osadzenie na prawie magdeburskim wsi Wyczerpy.

Wzm. z 1631 r.: sołtysi Andrzej Janowski i Jadwiga z Plok okazują dok. na założenie na 22 łanach na prawie magdeburskim wsi Wyczerpy. Król nadal sołtysowi 2 łany, trzeci denar od każdej sądzonej sprawy, prawo posiadania stawu z młynem, karczmy, jatki mięsnej, trzeciej części ogrodów, które będą się rozciągać aż do brzegu Warty. Soltys na wyprawę wojenną stawi się z kuszą na koniu wartości 2 grzywny. Na Wielkanoc kmiecie będą płacić po pól grzywny oraz dawać jaja i sery. Gdy król przybędzie do Częstochowy, kmiecie i sołtys będą płacić po 8 groszy na obiad dla niego. Czynsz $\mathrm{z}$ łanu po kopie groszy królowi i po 3 skojce dziesięciny, komu będzie przysługiwać. Dok. został wystawiony w Chęcinach in vigilia Nativitatis Beate Virginis Marie, czyli 7 września (AGAD, ASK XLVI, 42, k. 69, 70 - inwentarz starostwa olsztyńskiego z 1631 r., wg odpisu J. Laberscheka).

Uw. Według Gąsiorowskiego, Intinerarium, s. 190 przyp. 110, data dok. nie odpowiada trasie podróży króla, który 24 sierpnia był w Krzepicach, a 8 września w Powidzu. Wydaje się, że pisarz, wpisując obszerne streszczenie dok. do inwentarza, mógł zniekształcić jego datę.

5. W 1358 r. król nadaje prawo niemieckie wsi Kobylany i wsiom do niej przynależnym (należącym do komesa Janusza).

Reg. A. K a mińs ki, Nieznane karty z dziejów miasteczka Dukli, [w:] Prace z dziejów Polski feudalnej, Warszawa 1960, s. 430 - reg. z 1531 r. dok. Kazimierza W. wystawionego 22 VII 1358 r. w Krakowie. Por. SHG, cz. 2, s. 663 .

Uw. Już w 1359 r. komes Janusz herbu Grzymala, korzystając z zezwolenia królewskiego, jako dziedzic Kobylan z przyległościami, wystawił kontrakt lokacyjny dla swej wsi Leszczyny (A. K a m iń s k i, Nieznane karty, s. 430; SHG, cz. 3, s. 555). Data dok. króla nie budzi wątpliwości (Gąsiorowski, Itinererium, s. 191).

6. W 1360 r. król za wierną służbę rycerza Wierzbięty z Branic przenosi jego wsie: Branice, Stryjów, Wolę (Rusiecką), Zimny Brzeg (dziś Zymbrzeg) i Szczurów z prawa polskiego na średzkie.

Reg. dok. wystawionego w Niepolomicach in octava s. Martini episcopi (18 listopada) anno incarnacionis Domini zamieścil B. Pa procki, Herby rycerstwa polskiego, wyd. J. Turowski, Kraków 1858, s. 130.

Uw. Dok. ten pominął Gąsiorowski, Itinerarium, s. 193. Datacja nie budzi jednak żadnych wątpliwości, gdyż 1 listopada król był w Jadownikach, 13 listopada - w Sandomierzu, 7 grudnia - w Krakowie, mógł więc 
z powodzeniem być 18 listopada w Niepolomicach. Dodać tu można, że B. Paprocki obok tego regestu zamieścił również reg. dok. Wladysława Jagiełly dla potomka rycerza Wierzbięty - również Wierzbięty, w sprawie prawa niemieckiego dla jego wsi Ruszczy, Mikluszowic (wieś zaginęła) i Grabia. Dok. zostal wystawiony w Nowym Mieście Korczynie, a jego data 10 III 1405 r. jest zgodna z itinerarium tego króla (ZDM 6, nr 1850; SHG, cz. 1, s. 206-208; A. Gą sio rowski, Itinerarium króla Wladyslawa Jagielly 1386-1434, Warszawa 1972, s. 46).

Odbiorca dok. Kazimierza Wielkiego Wierzbięta z Branic 30 VII 1360 r. był przy królu w Koprzywnicy, gdzie świadkował na jego obszernym dok. dla tamtejszego klasztoru cystersów (KDM 1, nr 258 - tu z błędną datą 25 czerwca, por. Gąsiorowski, Itinerarium, s. 193).

7. Przed $1361 \mathrm{r}$. król zezwala Ocie z Pilicy na przeniesienie na prawo niemieckie jego dóbr w całym dystrykcie pileckim.

Wzm. z 1401 r.: Jadwiga - wdowa po Ocie z Pilicy, llitteris regalibus dowiodła, ze jej wieś Dobra (w par. Pilica) cieszy się prawem niemieckim. Totusque districtus Pilcensis similiter gaudet iure eodem teutonico. $\mathrm{Z}$ kolei w 1402 r. Jadwiga przez okazanie dok. króla Polski Kazimierza dowiodła, quod scoltetus de Wola ipsius, sibi pro quibuslibet rebus coram rege vel in iudicio generali suo, semper debet respondere iure sibi competenti, aut coram domino siue herede ville predicte (SP 2, $\mathrm{nr} 737,877$; TC 3, s. 392).

Uw. W 1361 r. Ota z Pilicy nabył Klimontów i Siedlec. W 1363 r. Kazimierz Wielki za zasługi w zarządzie Rusi nadał Ocie prawo magdeburskie dla tych dwóch wsi wraz $\mathrm{z}$ immunitetem sądowym (KDM 1, nr 262, 272). Gdyby przyzwolenie na prawo niemieckie dla swych dóbr dziedzicznych Ota uzyskał po 1361 r., automatycznie objęłoby również owe dwie wsie i nie byłoby potrzeby starań o osobny dok. w 1363 r. Lokację miasta Pilicy przeprowadził Ota w trzeciej ćwierci XIV w. (Kartoteka Pracowni) i właściwie wszystkie wsie klucza pileckiego w końcu tego wieku rządzily się prawem niemieckim. Proces ten musial się rozpocząc około połowy XIV w.

8. W 1361 r. król wystawia dokument lokacyjny dla swego miasta Lanckorony i określa uposażenie wójta.

Wzm. z 1366 r. o niedawno założonym mieście Lanckoronie (KDM 1, 185). Kolejna wzm. w lustracji starostwa lanckorońskiego z XVII w. (AGAD, ASK LVIII, nr 24, k. 294). Obszerne streszczenie tego zaginionego dok., kładąc główny nacisk na uposażenie wójta, zamieścili M. B a liński i T. Li piński, Starożytna Polska, t. 2, Warszawa 1844, s. 234; por. F. K i r y k, Rozwój urbanizacji Malopolski XIII-XVI w. Województwo krakowskie (powiaty poludniowe), Kraków 1985, s. 237, 238; Z. P e r z a n o w s k i, Lanckorona, [w:] Ojczyzna bliższa i dalsza, Kraków 1993, s. 163-165; SHG, cz. 3, s. 423.

9. Przed 1363 r. król nadaje dziedzicom Dobrociesza i Druszkowa immunitet sądowy wraz $\mathrm{z}$ prawem niemieckim dla tych wsi. 
Wzm. z 1420 r.: sąd ziemski zachowuje Jakuba Ciechosza z Druszkowa $\mathrm{w}$ sporze $\mathrm{z}$ Andrzejem $\mathrm{z}$ Druszkowa przy przywilejach zawartych $\mathrm{w}$ okazanym dok. króla Kazimierza. Jakub nikomu nie będzie odpowiadać przed sądem kasztelana sądeckiego w Nowym Sączu; wzm. z 1424 r.: sąd wiecowy uwalnia Stanisława z Dobrociesza w sporze z Piotrem z Kątów od sądownictwa kasztelana sądeckiego w Nowym Sączu na podstawie okazanego dok. króla Kazimierza. In quo privilegio continetur, quod ipse Stanislaus ex progenitoribus suis in nulla castellania citatus et citandus habet alicui respondere. Et iudicium eundem Stanislaum circa ipsum privilegium remansit (TC 7, s. $10,11,333)$.

Uw. W 1363 r. Kazimierz Wielki za zashugi Floriana z Druszkowa przeniósł na prawo średzkie jego wsie Wojakową, Płom i Kąty w ziemi sądeckicj oraz U Dęba, czyli Gieraszów przed Wieliczką. W 1367 r. wieś Dobrociesz należała do dziedziców Druszkowa (KDM 3, nr 766, 803). Wsiom Dobrciesz i Druszków król nie nadawał prawa niemieckiego dok. z 1363 r., w którym Florian został określony jako dziedzic Druszkowa. Wsie te musiały już zatem korzystać $\mathrm{z}$ prawa niemieckiego nadanego im osobnym dokumentem króla przed 1363 r. Przyjmuję, że to był, obecnie zaginiony, dok. okazywany w sądach w latach 1420 i 1424 . Jego odbiorcą był zapewne zashużony rycerz Florian, który wówczas dysponował znacznym majątkiem, ale nie byl już jedynym dziedzicem Druszkowa i Druszkowa Pustego (SHG, cz. 1 , s. $605-612$ ).

10. Po 1363 r., a przed 1370 r. król poświadcza, że Jakusz z Raszkowa opisał żonie Małgorzacie posag i wiano na swych dobrach.

Wzm. z 1417 r.: sąd ziemski oddalił pozew Jana z Raszkowa przeciw stryjence Małgorzacie - wdowie po Jakuszu z Raszkowa, a następnie wdowie po Klemensic z Wężerowa. Posag i wiano opisane przez pierwszego męża, zgodnie z tenorem dok. króla Kazimierza, pozostaną dożywotnio w dyspozycji Małgorzaty. Po jej śmierci Jan odbierze sobie tyle, ile prawnie będzie mu przyshugiwać (TC 6, s. 302).

Uw. Jakusz $z$ Raszkowa $w$ pow. lelowskim nie został bezpośrednio poświadczony przez źródła z czasów Kazimierza Wielkiego. W 1363 r. tenże król, wynagradzając zasługi Klemensa dziedzica Wężerowa, uwolnił jego i jego matkę Stachnę oraz ich kmieci z Wężerowa, Zdziesławic i Pruski od sądownictwa urzędników królewskich (ZDM 1, nr 104). Wydaje się więc, że jeszcze wówczas Klemens nie był żonaty. Małgorzata, czyli Machna, była wdową po nim co najmniej od 1384 r. Od 1396 r. występowali w źródłach: Dzierslaw, Florian i Piotr - synowie jej i Klemensa (SP 8, nr 2846, 4430, 7313, 7514, uwaga 61/12,63/13, 65/27, 53/2, 55/7, 258/6, 260/90, 268/15, 271/15). Bratanek Jakusza Jan z Raszkowa był synem Dobiesława, występował w latach 1388-1423 (Kartoteka Pracowni). Małgorzata w 1417 r. musiała już być nader sędziwą niewiastą. 
11. W 1364 r. król zatwierdza zamianę wsi Kobylany, Zagórze i Łęki oraz innych.

Reg. A. Kamiński, Nieznane karty, s. 429 - wg niejasnego regestu z 1531 r.; por. SHG, cz. 2, s. 638 i przyp. 2.

Uw. Dok. został wystawiony 21 X 1364 r. na Węgrzech. Według Gąsiorowskiego, Itinerarium, s. 197, przyp. 177, data ta jest całkiem wątpliwa, dlatego odnotował ją tylko w przypisie. Trudno jednak przejść do porządku nad datacją: sub data et actu in regno Vngariae die Undecim Milium Virginum Beatarum anno millesimo trecentesimo sexagesimo quarto. Nasuwa się pytanie, czy taką datację mógłby wymyślić ewentualny fałszerz? Może Kazimierz Wielki przez krótki czas nieoficjalnie przebywał $\mathrm{w}$ towarzystwie Ludwika Andegaweńskiego na pograniczu polsko-węgierskim, skąd mógł dojechać na 25 października do Szydłowa, bo przecież nie wiemy, gdzie polski monarcha przebywal od końca września do 25 października. Niewykluczone też, że pisarz zniekształcił $w 1531$ r. datację przedłożonego w sądzie dok. Trudno byłoby wskazać cel ewentualnego fałszerstwa. Przyjmuje zatem, że jeszcze w $1531 \mathrm{r}$. istniał autentyczny dok. Kazimierza Wielkiego w sprawie zamiany dóbr kobylańskich.

12. W 1364 r. król wystawia dok. lokacyjny dla wsi Krasawy w tenucie olsztyńskiej.

Wzm. z 1564 r.: sołtys Krasawy okazuje lustratorom dok., według którego do solectwa należą 2 lany, karczma, ogród, szósty denar z czynszów i trzeci denar z opłat za sądzone sprawy. Sołtys płaci wicne, czyli obiedne (Lustracja województwa krakowskiego z r. 1564, t. 2, wyd. J. Małecki, Warszawa 1964, s. 30,141 , nr 51; SHG, cz. 3, s. 132).

13. W 1366 r. król lokuje na prawie magdeburskim miasto Jasło, któremu między innymi wyznacza tereny pod ogrody, nadaje wagę i 2 wolne lany na skotnice. Mieszczanie nullibi iudicari debent, nisi in iure ipsorum civili coram advocato.

Wzm. z lat 1569 i 1660: streszczenie fragmentu... do skotnicy z data i miejscem wystawienia (ZDM 1, nr 116; F. K iry k, Rozwój urbanizacji Malopolski, s. 72, 73). W 1419 r. rajcy miasta Jasła pozwani przez współmieszczaniana Miczka przed sąd leński w Bieczu okazali dok. króla Kazimierza $\mathrm{z}$ klauzulą sądowniczą, a sąd ten odesłał sprawę ad ius ipsorum. Ten dok. mieli okazać mieszczanie w $1418 \mathrm{r}$. przed sądem ziemskim na rokach w Bieczu (TB 1a, s. 160; SP 2, nr 1584a; CB 2, s. 104; SHG, cz. 2, s. 257).

Uw. Powtórzono tu wydaną już wzmiankę o zaginionym dok. króla, ponieważ wiadomość z 1419 r. uzupelnia jego fragmentaryczną treść.

14. W latach 1366-1370 król poświadcza, że wojewoda sandomierski Piotr Nieorza kupił część w Stępocicach.

Wzm. z 1403 r.: Piechna z Żeleźnikowej żona Adama oddaliła wieczyście roszczenia Nastki wdowy po Sułku z Góry i ich dzieci: Szymka, Piotra, Sułka i Heleny o część w Stępocicach należącą ongiś do Nieorzy wojewody 
krakowskiego (błędnie, zamiast sandomierskiego w latach 1366-1375), okazując dok. króla Kazimierza (TC 3, s. 543; SHG, cz. 1, s. 823). Piechna - żona Adama z Turu, była córką Piotra z Żeleźnikowej, wnuczką Śmila, prawnuczką wojewody Piotra Nieorzy.

Uw. W 1339 r. Kazimierz Wielki przeniósł z prawa polskiego na średzkie Stępocice należące do braci Bonifacego i Idziego oraz ich bratanków Damiana i Więcslawa - synów Piotra (KDM 3, nr 661). Tego dok. nie mogła okazać w sạdzie Piechna, gdyż Nieorza nie miał nic wspólnego z dziedzicami Stępocic z 1339 r. Nabyl on później dobra w tej wsi, co potwierdził Kazimierz Wielki. Odziedziczył je syn Nieorzy Śmił, poświadczony w 1389 r. jako dziedzic Stępocic (SP 8, nr 5229).

15. Przed 1370 r. król wystawia dok. lokacyjny dla wsi Alba Ecclesia (czyli Biały Kościól).

Wzm. z 1407 r.: Żegota z Grzegorzowic wyjął Tomka soltysa de Alba Ecclesia spod jurysdykcji sądu grodzkiego, okazując dok. króla Kazimierza (CC 1b, s. 88); wzm. z 1428 r.: Tomasz z Niedźwiedzia zobowiązuje się przedłożyć litteram fundacionis cum quoquidem privilegio swego sołtysa we wsi Alba Ecclesia (Sąd Wyższy Magdeburskiego Prawa, I - 8, s. 311 w APK).

Uw. Wieś Biały Kościól nie byla już własnością królewską w końcu XIV, ale długo utrzymywało się $w$ tej wsi dziedziczne sołectwo. Żegota z Grzegorzowic nie był dziedzicem, ale zastawnikiem w Białym Kościele. Nie mógł się więc posłużyć dok. Kazimierza Wielkiego dla Toporów i Starych Koni z 1366 r. w sprawie sądownictwa patrymonialnego, który nieraz okazywał $\mathrm{w}$ sądzie, gdy chodziło o poddanych $\mathrm{z}$ jego dziedzicznych wsi. $\mathrm{Z}$ kolei Tomasz był mężem Heleny - wdowy po Zaklice z Korzkwi i Białego Kościoła, i $z$ tego powodu gospodarowal $w$ tej wsi. Wynika $z$ tego, że w latach 1407 i 1428 chodzilo o dok. lokacyjny wystawiony przez Kazimierza Wielkiego (SHG, cz. 1, s. 68, 69; cz. 2, s. 115-118, 766-770).

16. Przed 1370 r. król potwierdza, że dziedzic Boczkowic jest szlachcicem herbu Leliwa.

Wzm. z 1399 r.: Przecslaw Strecz syn Floriana Niedomy z Boczkowic, po śmierci swego brata Stanisława Niedomy, dokończył oczyszczania naganionego bratu szlachectwa przez Paszka ze Slupowa. Przecslaw okazał w sądzie dok. króla Kazimierza, dowodząc prawa posługiwania się herbem Leliwa (SP 8, nr 8506).

Uw. Stanisław (1385-1397) i Przecsław byli synami Floriana, który zapewne był odbiorcą dok. Kazimierza W.

17. Przed 1370 r. król potwierdza dziedzicom Chronowa szlachectwo i herb Gryf.

Wzm. z 1404 r.: Andrzej - syn Stanisława, dziedzic z Chronowa, oczyścił naganione szlachectwo przez okazanie dok. Kazimierza Wielkiego i stawienie w sądzie świadków (SP 2, nr 1059). 
18. Przed 1370 r. król przyznaje dziedzicom Damic immunitet sądowy.

Wzm. z 1430 r.: w sporze pomiędzy Andrzejem - kmieciem z Damic, w części Jakuba Pieniążka, a braćmi Andrzejem i Tomkiem - dziedzicami innej części Damic, sąd grodzki nakazał tym ostatnim okazać w obecności kasztelana i starosty krakowskiego (Mikołaja Białuchy z Michałowa) dok. króla Kazimierza. W następnym roku sąd odesłał strony na wiec, jeśli będzie się odbywał przed przyjazdem króla do Krakowa. Gdyby król przybył wcześniej, staną przed królem, a Andrzej i Tomek okażą ów dok. (CC 4, s. $173,184,185)$.

Uw. Brak pewności, czy dziedzice Damic na pewno okazali dok. Kazimierza Wielkiego, ponieważ z $1431 \mathrm{r}$. nie zachowały się zapiski z sądu nadwornego i z wiecu generalnego. Uwzględniono jednak te wzmiankę, ponieważ nie da się również stwierdzić, że go nie okazali.

19. Przed 1370 r. król przenosi na prawo niemieckie wsie Sokolniki i Dzibice w starostwie lelowskim.

Wzm. z 1414 r.: Mikolaj soltys z Sokolników przez okazanie dok. króla Kazimierza dowodzi, że ww. wsie posiadaja prawo niemieckie, a ich mieszkańcy mają być sądzeni przez sołtysa królewskiego - quia incole cuilibet debent respondere nisi coram scolteto regis Kazimiri (TC 312, s. 54).

20. Przed 1370 r. król nadaje soltysowi Grodnej na osadzenie kmieci 24 lany i nie więcej, w zamian za rezygnację na jego rzecz z praw do łanów wykarczowanych ponad te liczbę $\mathrm{i}$ innych $\mathrm{w}$ granicach tej wsi.

Wzm. z 1398 r.: bracia Mikołaj Wierzba i Jakub z Grodnej w sporze z Władysławem Jagiełłą okazują w sądzie nadwornym dok. króla Kazimierza. Sąd zawyrokowal, że wszystkie lany powyżej 24 łanów będą należeć do króla lub sołectwa. Et nichilominus ipsi Nicolaus et Jacobus in dicta scoltecia efficiantur in perpetuum (SP 8, nr 7344; SHG, cz. 2, s. 57).

21. Przed 1370 r. król nadaje immunitet sądowy dziedzicowi Karwina i Raciechowic.

Wzm. z 1399 r.: Dorota - wdowa po Siecieju z Raciechowic, okazując w sądzie dok. króla Kazimierza, uwolniła swego kmiecia Jaszka z Karwina od stawania przed sądem ziemskim w jego sporze ze szlachetnym Wrochem $\mathrm{z}$ Wojsławic $\mathrm{i}$ jego kmieciem Stańcem. Dorota za okazanie tego dok. winna zapłacić 1 kopę groszy pamiętnego (SP 8, nr 8383, 8384).

Uw. Niewykluczone, że odbiorcą dok. był Sieciej, do którego należały Raciechowice i część w Karwinie. Został poświadczony w 1385 r. (SP 8, nr 3349). W przypadku Karwina nagromadzilo się sporo ciekawych „dokumentowych" wiadomości zapewne dlatego, że sprawy wlasnościowe w tej wsi były mocno skomplikowane. Część wsi należała do klasztoru tynieckiego, a w części szlacheckiej nastąpiło daleko idące rozdrobnienie. Warto na tym miejscu chociaż pokrótce omówić te dokumenty. 
W 1367 r. Kazimierz Wielki przeniósł kilkanaście wsi klasztoru tynieckiego z prawa polskiego na niemieckie. Wśród tych wsi został wymieniony Karwin (KDT, nr 98 niesłusznie uznany przez wydawcę za falsyfikat). Nie wiadomo, czy tym dok. posługiwal się klasztor np. w latach 1385 i 1419. W 1385 r. klasztorni kmiecie z Karwina (de Zaruin monachorum) mieli przedłożyć dok. przeciw Mikołajowi z Czernichowa. W tym też roku opat tyniecki okazal dok. stwierdzający, że jego kmiecie winni odpowiadać $w$ dobrach według prawa niemieckiego (SP 8, nr 3347, 3467). Z kolei kmiecie z Karwina należący do Jakusza i do Klemensa kasztelana radomskiego winni stawić przeciw Mikołajowi z Czernichowa i Karwina swoich panów i okazać w sądzie dok. prawa niemieckiego (SP 8, nr 3417, 3621, 3668). Sąd respektowal prawa klasztoru, skoro w 1399 r. sprawę Piotrasza z Sancygniowa ze Skorkiem i Goworkiem kmieciami z klasztornej wsi Modrzany decyzją sądu opat winien rozsądzić $\mathrm{w}$ Karwinie wedhug prawa niemieckiego (TC 2, s. 405; SHG, cz. 2, s. 449).

Wdowa po Siecieju Dorota prowadziła liczne procesy nie tylko z sąsiadami jej części w Karwinie, ale też Raciechowic. Na przykład w 1399 r. toczyła proces z Hanką - żoną Stanisława z Kunic, o dok. i łąkę. Z kolei Malgorzata - żona Lorka $z$ Libertowa, oddaliła jej roszczenia o gaj w Kunicach dok. sądowym (SP 8, uwaga 291/16, 293/30, nr 8916).

W 1419 r. sąd grodzki w sporze między szlachetnym Jaszkiem z Wierzbna a Piotrem kmieciem $\mathrm{z}$ klasztornej części Karwina pytał, czy kmieć ma odpowiadać przed tym sądem vel non scilicet in theutonico o zajętego wołu. Jaszek $\mathrm{z}$ Wierzbna naganił jednak przedłożony wówczas dok. księcia Leszka wystawiony dla klasztoru. Sąd wyznaczył w tej sprawie termin przed królem, po jego przyjeździe do Niepolomic (CC 1, s. 166, 172, 184). Najpewniej chodziło tu o dok. Leszka Czarnego z datą 1286, którym książę rzekomo zezwolil klasztorowi zakładać na prawie niemieckim miasta i wsie w granicach jego dóbr (KDT, nr 32). Wspomniany Piotr - kmieć z Karwina, w sporze z Jaszkiem z Wierzbna decyzją sądu winien okazać dok., że nie będzie odpowiadać przed sądem grodzkim, lecz w Karwinie zgodnie ze swym prawem niemieckim (CC 1, s. 217, 219, 240). Sąd nadworny na sesji w Niepolomicach odeslał do rozpatrzenia na najbliższy wiec $w$ Krakowie sprawę Jaszka z Wierzbna $\mathrm{z}$ opatem tynieckim o dok. księcia Leszka dotyczący prawa niemieckiego (TC 6, s. 609).

W 1449 r. Stanisław Sypiel - kmieć opata tynieckiego z Karwina, pozwal trzech kmieci Tomasza $z$ Karwina o zadane mu rany. Tomasz przedłożył dok. prawa niemieckiego, wyjmując swoich poddanych spod jurysdykcji sądu grodzkiego (CC 10, s. 839, 840). Był to być może zaginiony dok. Kazimierza Wielkiego sprzed $1370 \mathrm{r}$.

22. Przed 1370 r. król nadaje Zygmuntowi z Cichawy lub jego ojcu Jakuszowi wieś Kasinę Wielką. 
Wzm. z 1403 r.: Zygmunt (ongiś z Cichawy) - obecnie wójt Dębowca, sprzedaje wsie Kasinę Wielką i Rabkę za 1 tys. grzywien groszy praskich wojewodzie lęczyckiemu Janowi Ligęzie. Tą pierwszą z takimi prawami, $\mathrm{z}$ jakimi ją sam posiada, zgodnie $\mathrm{z}$ treścią dok. króla Kazimierza (SP 2, nr 1010).

Uw. Jakusz z Cichawy herbu Pólkozic występował w latach 1375-1381. Jego syn Zygmunt byl dziedzicem Cichawy w latach 1388-1399, a w latach 1399-1403 był dziedzicznym wójtem Dębowca (SHG, cz. 1, s. 395, 396, 542). Pierwsza wiadomość o Kasinie Wielkiej pochodzi z 1398 r., a o Rabce - z 1402 r. (SHG, cz. 2, s. 450, 451; TC 3b, s. 93).

Zygmunt z Cichawy próbował sprzedać Kasinę w 1398 r., ale wywołało to protesty krewnych. W $1401 \mathrm{r}$. z roszczeniami z racji bliższości wystąpił między innymi Jan Ligęza - późniejszy nabywca tej wsi i Rabki. Pierwszym nabywcą był Andrzej - dziedzic Skrzydlnej i Korabiowic, podkomorzy mazowiecki. Odstąpil on swych praw w 1402 r. na rzecz Ligęzy. Ten procesował się też z braćmi Birową, Spytkiem i Klemensem z Banowic o Rabkę. Na przykład w tym roku jego termin z Klemensem został przełożony do czasu aż wróci $z$ wyprawy wojennej. W 1403 r. Jan Ligęza, po sfinalizowaniu transakcji kupna z Zygmuntem Cichawskim, pozwał Andrzeja ze Skrzydlnej o dok. dotyczący wsi Kasiny (TC 3a, s. 590; 3b, s. 93). W następnym roku $\mathrm{w}$ tej sprawie wyrokowal sąd ziemski krakowski. Andrzej utrzymywał, że dok. tego już nie posiada (ipsam litteram privilegialem super villa Cassyna iam non habere), wobec tego sąd zadecydował: gdyby kiedykolwiek Andrzej lub ktoś inny dok. ten wydobył i okazywał, nie będzie on mial żadnej mocy i nie będzie mógł być wykorzystany przeciwko wojewodzie łęczyckiemu (Dokumenty sqdu ziemskiego krakowskiego, wyd. Z. Perzanowski, Kraków 1971, nr 112). Nie ulega wątpliwości, że spór toczył się o dok. Kazimierza Wielkiego, na który powoływał się Zygmunt Cichawski.

23. Przed 1370 r. król wystawia dok. w sprawie dziedziny Kąty.

Wzm. z 1398 r.: Jaszek z Woli Dulębiny i jego siostra Machna zeznaniami świadków oczyścili naganiony przez Dobka z Cieklina dok. króla Kazimierza na dziedzinę Kąty i pozyskali sprawę o tę dziedzinę oraz o 100 zagonów roli (SP 8, nr 7582).

Uw. Najpewniej dok. królewski zawierał zezwolenie na prawo niemieckie. Po lokacji wieś nazywano Wolą Dulębiną, a później Duląbką. Świadczą o tym dane z lat 1397 i 1397: Dobek z Cieklina przeciw Jaszkowi i Machnie o pola i szkody; świadkowie ze strony Jaszka i Machny zeznali, że Dobek ne bil gospodarzem any $w$ trzimanu dziedzini Dulalanky nigdi taco, iaco na prziwileyw stogy (SP 8, uwaga 229/101-103, nr 6388).

24. Przed 1370 r. król nadaje Janowi Borkowi - stolnikowi sandomierskiemu, część Lgoty i Niesułowice, względnie potwierdza posiadanie nabytych przezeń tych dóbr. 
Wzm. z 1427 r.: Hanusbork - mieszczanin krakowski, oddalił roszczenia swego brata przyrodniego Jana - syna Jana Chełmskiego, o część w Niesułowicach i Lgocie przysługującą mu - jak twierdził - po matce. Hanusbork okazał w sądzie dok. króla Kazimierza opieczętowany jego pieczęcią, dowodząc, że te dziedziny odziedziczył po ojcu, a nie po matce Katarzynie (TC 146, s. 41, 42). Sąd wiecowy odesłał jednak do sądu miejskiego pozew Jana Chetmskiego z Chełmu i jego syna Jana przeciw Hanusborokowi o klejnoty, złoto i srebro oraz szaty i inne rzeczy wartości 200 grzywien. Po śmierci matki Katarzyny bracia przyrodni i ojciec Jana dokonali podziału, ale Hanusbork zabrał także część Chełmskich, którzy mogą te rzeczy odzyskać na drodze sądowej według prawa miejskiego (SP 2, nr 2124).

Uw. Jan Bork (Hanusbork) byl stolnikiem sandomierskim w latach 1360-1376. Skupowal części w Parczach (patrz niżej), które odziedziczyl jego syn Piotr Bork. W pobliżu leżały wsie Lgota i Niesułowice. W $1388 \mathrm{r}$. Jan i Piotr - synowie stolnika, sprzedali Grzegórzki. Jan Hanusbork, poświadczony w latach 1427-1450, był zapewne synem Piotra (Kodeks dyplomatyczny miasta Krakowa, t. 1, wyd. F. Piekosiński, Kraków 1879, nr 66, 69; SP 2, nr 2203, 3119, 3251; CC 3, s. 266; TC 150, s. 288; SHG, cz. 3, 578).

25. Przed 1370 r. król powierza niejakiemu Piotrowi osadzenie wsi Lipskiej Woli (dziś Lipna Wola) na prawie niemieckim.

Wzm. z 1433 r.: kmiecie z Kacic pozwali do sądu grodzkiego kmieci z Lipskiej Woli o pobicie. Kasztelan brzeski Stanisław Jelitko okazał dok. króla Kazimierza z jego pieczęcią majestatyczną, wyjmując swych kmieci spod jurysdykcji grodzkiej. W zapisce przytoczono obszerny fragment dok. Kazimierza W., w którym byla następująca klauzula: Insuper absolvimus eundem scultetum Petrum et suos successores nec non kmetones prefate ville ab omnibus iudiciis palatinorum, castellanorum et quorumlibet iudicum, subiudicum nostri Regni et penitus liberamus. Ita quod coram ipsis vel eorum aliquo pro causis magnis et parwis nulli debeant respondere nisi kmetones coram suo sculteto iure theutonico respondebunt scultetus vero non alias nisi coram nobis dum per litteram nostram sigillo nostro sigillatam fuerit evocatus tunc de se querulantibus non aliter tamen quam suo iure theutonico respondebit etc. Dalej sąd orzekał: Quod quidem privilegium auscultantes dictum dominum castellanum Brzesensem circa ipsius tenorem et ius remanentes decrevimus homines ipsius ad hereditatem remittendos iudicari (CC 4, s. 28, 29).

Uw. Stanislaw Jelitko z Goznej w 1411 r. uzyskał od Wladysława Jagielly zapis 100 grzywien na Lipskiej Woli (ZDM 6, nr 1759). Z 1429 r. pochodzi ciekawa wiadomość o rzekomym prawie własności Stanislawa do tej wsi. Soltys z Lipskiej Woli procesowal się z Wojciechem -- kmieciem z Wilczkowic. Stanisław z Goznej miał przedłożyć w sądzie grodzkim dok. królewski, jeśli takowy posiada, potwierdzający, że ma tę wieś od króla cum omni iure et 
dominio, wówczas Jan sołtys Lipskiej Woli będzie odpowiadał przed nim według prawa niemieckiego, w przeciwnym razie soltys stanie przed sądem grodzkim (SP 2, 2283). Kasztelan brzeski tej treści dok. Wladysława Jagiełły oczywiście nie mógl okazać, ponieważ miał tylko zapis na tej wsi, która po 1411 r. była nadal własnością monarszą. Lipska Wola została lokowana na prawie niemieckim. W $1396 \mathrm{r}$. został poświadczony syn sołtysa Marcina Andrzej, który po ojcu objąl w 1398 r. solectwo w tej wsi (ZDM 1, 213; SP 8, nr 6602, uwaga 264/15). Nie wydaje się, aby w 1429 r. nie było we wsi dok. lokacyjnego i spreparowano go dopiero około r. 1433. Kasztelan brzeski być może próbował "przywłaszczyć" sobie prawa własności do trzymanej od lat $\mathrm{w}$ tenucie Lipskiej Woli, co z góry zakwestionowal sąd, poddając $w$ wątpliwość istnienie odpowiedniego dok.

26. Przed $1370 \mathrm{r}$. król przenosi $\mathrm{z}$ prawa polskiego na niemieckie wieś Lagiewniki należącą do Tomka Litwina.

Wzm. z 1424 r.: 26 września Anna z Lagiewnik - wdowa po Dziersławie (córka Tomka Litwina i Krystyny z Rgilewa w ziemi lęczyckiej i Zbylucic z ziemi sieradzkiej), po okazaniu w sądzie ziemskim dok. króla Kazimierza wyjmuje swoich kmieci z Lagiewnik z tego sądu i będzie ich sądzić w swojej dziedzinie (TC 7, s. 404); 7 grudnia Piotr z Lagiewnik (syn Anny i Dziersława) okazal w sądzie grodzkim dok. króla Kazimierza. Zgodnie z jego treścią, idem Petus et ipsius familia kmetones et incole omnes et singuli ibidem in Lagieuniki ac ubicunque eos habere dinoscitur coram nullis iudicibus subiudicibus castellanis capitaneis dignitariis et quibusvis officialibus nulli de se querulanti debeant respondere pro omnibus causis tam magnis quam parvis puta furti sanguinis homicidi et incendi nisi tantum coram ipso (CC 2, s. 296, 297).

Uw. Zarówno Anna, jak i Piotr odprawili sądy w Lagiewnikach; por. SHG, cz. 3, s. 800, 805. Tomek Litwin pisal się z Konar i Lagiewnik; występowal w latach 1375-1395; on najpewniej był odbiorcą dok. Kazimierza W. Ciekawe, że obydwie wsie Tomka pierwotnie należały do osad służebnych, najpewniej nadanych mu przez tego króla. W Konarach sołectwo zostało poświadczone w 1398 r., wydaje się zatem calkiem słuszny wniosek, że Kazimierz Wielki w swoim dok. przeniósł na prawo niemieckie również tę wieś; por. SHG, cz. 2, s. 734.

27. Przed 1370 r. król nadaje wsi rycerskiej Łęki prawo niemieckie wraz $\mathrm{z}$ immunitetem sądowym.

Wzm. z 1414 r.: Grzegorz z Łẹk w sporze z Klemensem Uchaczem okazał w sądzie ziemskim w Krakowie dok. króla Kazimierza dowodząc, quod non habet coram castellanis, palatinis, iudicibus vel subiudicibus in terminis parvis nisi coram rege vel in colloqio generali respondere (TC 6, s. 28).

Uw. W 1414 r. Klemens Uchacz - sędzia kasztelana sądeckiego Krystyna Koziegłowskiego, oddalił pozew Grzegorza z Lęk o to, jakoby nie chciał zachować go przy jego przywilejach (TC 5, s. 414; SHG, cz. 3, s. 926). 
W latach 1410-1412, po procesie, Andrzej z Lęk naganiony przez Mikołaja Rogalca $z$ Wróblowic oczyścil szlachectwo dok. wystawionym dla jego stryja Grzegorza (SHG, cz. 3, s. 927). Może to był zaginiony dok. Kazimierza Wielkiego, okazany w 1414 r., a może też zaginiony jakiś inny dok.

28. Przed 1370 r. król nadaje dziedzicom Naszacowic (dziś Naszczowice) immunitet sądowy.

Wzm. z 1415 r.: Jan z Naszacowic okazał w sądzie ziemskim w Krakowie dok. króla Kazimierza, że non habet nec tenetur in iudicio castellani Sandecensis cuiquam respondere, nisi coram domino rege vel in iudicio terrestri Cracoviensi, contra Pelcam ibidem de Nassaczouice et contra quemlibet respondeat (TC 6, s. 162).

Uw. W 1333 r. zostal poświadczony Pawel dziedzic Naszacowic, a w 1353 r. - Ścibor i Wierzbięta (KDM 3, nr 632; ZDM 1, nr 75). Ci ostatni być może byli odbiorcami dok. Kazimierza Wielkiego.

29. Przed 1370 r. król poświadcza, że Zdziesława z Ochonina (dziś Ochojno) sprzedała dziedzinę $w$ tej wsi.

Wzm. z 1402 r.: sześciu świadków ze strony Piotra z Ochonina przeciw Klemensowi z Ochonina zeznało i poświadczyło, że trzy pola zwane niwami, o które toczył się spór, należą do części dziedziny w Ochoninie sprzedanej przez Zdziesławę, zgodnie $\mathrm{z}$ treścią dok. króla Polski Kazimierza (TC 3a, s. 537).

Uw. W latach 1401-1402 Piotr i Klemens - dziedzice w Ochoninie, toczyli spory o części w tej wsi. Na przykład w 1401 r. sąd nakazal Piotrowi ustąpić Klemensowi $1 / 6$ dziedziny, którą mu przysądził. Tego też roku Klemens prawnie pozyskał część dziedziny, o którą była wizja, na Piotrze Wierzchonowicu, ponieważ jeden $z$ jego świadków nie chcial przysięgać (TC 3a, s. 238 i n.; 3, s. 258,276 ).

Datę 1349 ma dok. Kazimierza Wielkiego, którym potwierdzal podzial Ochonina i Lukanowic (ZDM 1, 57 - data nie odpowiada świadkom), ale treści tego mocno podejrzanego dok. nie da się $w$ żaden sposób powiązać z wiadomością o dok. tego króla w zapisce z 1402 r. W 1373 r. zostali poświadczeni dziedzice w Ochoninie: Rafal, Pabian, Jan i Miłosz (KDK 2, nr 285, 286). Któryś z nich być może był jedną ze stron potwierdzonej przez Kazimierza Wielkiego czynności kupna-sprzedaży. Sprzedająca swoją część Zdziesława nie występuje w zachowanych źródłach.

30. Przed 1370 r. król poświadcza szlachectwo Jana z (nieistniejących dziś) Ocięsławic i nadaje mu immunitet sądowy.

Wzm. Z 1400 r.: Wojtek - syn Jana z Ocięsławic, naganiony przez Miłka - młynarza z pobliskiego Brzezia, okazał dok. króla Kazimierza super iure nobilitatis et milicie suis, według którego a iudicio et iurisdictione omnium palatinorum et castellanorum est exceptus et per litteram citacionis per quempiam debet citari (SP 8, nr 10912). 
Uw. Tego dnia - 1 grudnia Miłek został skazany na kare XV na rzecz Wojciecha z Ujazdu i sądowi za niesłuszną naganę (SP 8, nr 10911). Wojciech zwany Ociosna $\mathrm{z}$ Ocięsławic i Ujazdu pieczętowal się herbem Nowina, w źródłach został poświadczony w latach 1389-1430. Ocięsławice krótko po 1420 r. zostały wlączone do Ujazdu, w którym Wojciech miał część. Zauważyć tu trzeba, że Wojciech Ociosna należał do ciekawszych postaci w pierwszej ćwierci XV w. i zachowało się dużo i różnorodnych dotyczących go wiadomości źródlowych (SP 8, nr 5054, 5056, 5171, 5926, 5927, 7518, 7572, 7702, 7939, 7984, 9723, 10740, 10877, 10903, 10911, 10912; TC 3, s. 204, 209, 327, $441,452,457,462$, 592; 4, s. 4, 266; 5, s. 5, 209, 279; 6, s. 103, 180, 205, 208, 347, 409, 412, 417, 422, 548, 597; 8, s. 71; 9, s. 197; Kartoteka Pracowni).

31. Przed 1370 r. król nadaje marszałkowi Przedborowi z Brzezia i Wodzisławia $w$ dożywocie zamek Ogrodzieniec $\mathrm{z}$ wsiami.

Wrm. z 1387 r.: Władysław Jagiełlo nadał Włodkowi z Charbinowic - cześnikowi krakowskiemu, zamek Ogrodzieniec, który dostał w dożywocie marszałek Przedbor - jak to wynika z przedłożonego przez niego królowi dok. Kazimierza Wielkiego. Przedbor dostal w zamian zamek i miasto Dobczyce (ZDM 6, nr 1531 - reg.; Kolekcja pergaminów Tomasza Niewodniczańskiego, A 19 - or. dok. Jagiełły; Katalog dokumentów, nr 21).

32. Przed $1370 \mathrm{r}$. król określa powinności i obowiązki kmieci wsi Olszanicy należącej do klasztoru norbertanek zwierzynieckich.

Wzm. z 1421 r.: 28 czerwca sześciu świadków ze strony prepozyta i ww. klasztoru przysięgało, że wiedzą i poświadczają, iż król Kazimierz nadał przywileje kmieciom Olszanicy bez zgody prepozyta i klasztoru. Dok. ten klasztor unieważnil wobec starosty krakowskiego, a sąd zarządził, że kmiecie będą wykonywać robocizny, jakich domagał się od nich prepozyt. Pięciu $\mathrm{z}$ owych świadków przysięgało super certa destructione dicti priuilegii, a szósty, że dowiedział się o tym (SP 2, nr 1818 - wydawca opuścił imiona wymienionych w księdze świadków; CC 1, s. 535).

Uw. 26 VII 1421 r. sąd grodzki zawyrokowal, że kmiecie mają pracować dla klasztoru dwa dni $w$ tygodniu, a $w$ żniwa trzy dni, płacić stacje dla króla (SP 2, nr 1822). 2 września tego roku w sądzie nadwornym wymienieni $\mathrm{z}$ imienia kmiecie $\mathrm{z}$ Olszanicy $\mathrm{z}$ upoważnienia całej wiejskiej społeczności zwolnili wieczyście klasztor ze sprawy pro priuilegio hereditario (SP 2, $\mathrm{nr} 1797$ ).

33. Przed 1370 r. król poświadcza, że Paszek z Parcz sprzedał Janowi Borkowi dziedzinę w Parczach.

Wrm. z 1399 r.: sąd oddalił pozew Piotra Borka z Parcz, ponieważ sześciu świadków przywiedzionych przez Wojciecha z Parcz zeznało, że jego ojciec Paszek nie sprzedał Janowi Borkowi - ojcu Piotra, części dziedziny ojczystej w tej wsi, o którą Piotr go pozywal, okazując w tej sprawie dok. króla Kazimierza. Sąd uznał wizję woźnego sądowego za korzystną dla Wojciecha (SP 8, nr 8476). 
Uw. Spór o dziedzinę rozpocząl się w 1397 r., gdy sąd ziemski rozpatrywał pozew Piotra Borka przeciw Wojciechowi i jego matce Piechnie pro expulsione aratri, a sprawę o dziedzinę odesłał na wiec. W 1398 r. Piotr przywiódł świadków, którzy zeznali, że Piotr (!) kupil część w Parczach, a Wojciech nie gospodarzył na niej. Wnet Wojciech został skazany na kary, ponieważ powiedział Piotrowi: ...melior sum quam tu. Z kolei w 1399 r. świadków stawił Wojciech. Ci zeznali, iż Paszek nie sprzedał dziedziny Handzilborconi (czyli Janowi Borkowi, SP 8, nr 5949, 6621, 7740, 8236).

W latach 1365-1368 Kazimierz Wielki pięcioma dok. poświadczał Handzlinowi Borkowi kupno różnych czẹści w tej wsi (ZDM 4, nr 980, 986, 989, 992, 994). W tym ostatnim dok. wśród czternastu sprzedających części został wymieniony Paweł zw. Święch. Trudno jednak utożsamiać go z ojcem Wojciecha, gdyż najpewniej jeszcze w 1397 r. żyło przynajmniej kilku ze sprzedających swe cząstki w 1368 r. Może żyłby jeszcze sam Paszek, gdyby nie zostal zabity przed $1397 \mathrm{r}$. (SP 8, nr 6088). W tym roku żyła matka Wojciecha. Przyjmuję, że Piotr Bork miał (szósty) dok. Kazimierza w sprawie dziedziny w Parczach, który zaginął.

34. Przed 1370 r. król udziela immunitetu sądowego dziedzicom Roztoki i nadaje tej wsi prawo niemieckie.

Wrm. z 1428 r.: Jan - dziedzic z Roztoki, pozwał Klemensa - równieź z Roztoki. Ten na rokach w Czchowie okazal dok. króla Kazimierza, quod nullibi debeat respondere nisi coram rege dum per litteram regalem fuerit citatus aut coram iudice ipsius generali. Et coram palatino castellano iudice et subiudice et coram camerariis nullibi debeat respondere. Sąd zachował Klemensa przy jego przywilejach (TCz. 3, s. 35).

Uw. Pierwsze bezpośrednie wiadomości o Roztoce poczynają się od 1400 r. (SP 8, nr 11130). Istnieje też druga wieś o tej nazwie i także w powiecie sądeckim. W 1357 r. Kazimierz Wielki przeniósł wsie: Dębno, Wolę Dębińską, Sufczyn, Wolę Sufczyńską i Roztokę należące do Piotra ze Szczekocin z prawa polskiego na magdeburskie (ZDM 1, nr 83). Ta Roztoka cały czas należała do Piotra (o nim więcej informacji przy wzmiance z 1355 r.) i do jego potomków. Klemens dziedziczył w innej Roztoce, dysponował więc zaginionym dziś dok. tego króla dla jego wsi (por. TCz. 1, s. 196; 2, s. 76, 216; 3 , s. $34,35,53)$.

35. Przed 1370 r. król nadaje prawo średzkie wsi Rzeplin wraz z immunitetem sądowym.

Wzm. z 1424 r.: szlachetny Piotr Cianowski z Cianowic okazał sądowi grodzkiemu dok. króla Kazimierza, którym nadal wsi Rzeplin prawo średzkie $\mathrm{z}$ immunitetem sądowym. Ita, quod nullus capitaneorum, castellanorum, officialium seu iudicum aut subiudicum vel dignitariorum prefatos homines kmetones ac incolas ville antedicte Rzeplin debeat iudicare nisi kmetones et incolas ville prefate scultetus ipsorum et scultetum dominus ipsius valebit et 
debebit iudicare in omnibus causis tam magnis quam parvis excludendo omnes et singulas consuetudines que dictum ius thewtunicum consueverunt perturbari (!, CC 2, s. 257).

Uw. Piotr okazał ten dok. 26 IV 1424 r., a 12 września stawali przed sądem: Jakub - ongiś sołtys w Rzeplinie, przeciw Marcinowi - obecnemu sołtysowi w tej wsi. W sprawie tej 26 września sąd zawyrokował, że Piotr Cianowski do dwóch tygodni rozsądzi spór między sołtysem rzeplińskim a Jakubem, który wówczas zamieszkiwał przy ul. św. Floriana w Krakowie. Wnet, bo 10 października Cianowski pozwał Jakuba do sądu grodzkiego, ponieważ wiedział on, że jego sprawa ma być sądzona w Rzeplinie przez dziedzica; mimo to pozwal jego soltysa Marcina do sądu grodzkiego. Jakub twierdził, że tego nie wiedzial i 24 października przysięgał, quod non scivit ius in ibidem contra Petrum Czianowsky (CC 2, s. 248, 257, 268, 275).

Sołectwo w Rzeplinie poświadczają źródła od końca XIV w. W 1392 r. Małgorzata Kuklina - żona Macieja z Krakowa, miała okazać w sądzie wyższym prawa niemieckiego dok. w sprawie solectwa w Rzeplinie poświadczający, że wieś cieszy się prawem niemieckim. W 1394 r. Małgorzata sprzedała sołectwo (jego część) w Rzeplinie za 25 grzywien Jakubowi - ówczesnemu sołtysowi w tej wsi. W 1404 r. soltys Jakub miał okazać privilegium hereditarium na solectwo i objaśnić prawa kmieci (KSN, nr 115, 138, 154, 162, 163, $171,179,317,1377)$. We wspomnianych zapiskach chodziło o zaginiony dok. Kazimierza Wielkiego, który był okazywany w 1424 r.

36. Przed 1370 r. król poświadcza, że Jaszek z Sąspowa zastawił Prandocie z Sąspowa za 30 grzywien połowę karczmy w tej wsi.

Wrm. z 1398 r.: sąd nakazuje okazać dok. (króla Kazimierza) w sprawie pieniędzy, por. uw.; wzm. z 1399 r.: Franczek - syn Jaszka z Sąspowa, na wiecu w Krakowie potwierdzil Franczkowi - synowi Prandoty, prawo do 7 1/2 grzywny czynszu z 2 lanów pozyskanych w Sąspowie; Franczek - syn Prandoty, przez okazanie dok. króla Kazimierza udowodnil, że jego ojcu zostala zastawiona za 30 grzywien polowa karczmy w Sąspowie. Tenże Franczek będzie trzymać 2 łany i pół karczmy do czasu aź Franczek - syn Jaszka, zapłaci mu $71 / 2$ grzywny za lany i 6 grzywien za połowę karczmy (SP 8, nr 8257).

Uw. W 1381 r. został poświadczony Jaszek z Sąspowa (SP 8, nr 618). Byl to zapewne ojciec, obok Prandoty, jednego z Franczków procesujących się w 1399 r. Ten dok. dowodzi, że Kazimierz Wielki potwierdzal nawet wręcz drobne transakcje. Od 1397 r. proces z Franczkiem - synem Jaszka, toczyli Franczek i Prandota - synowie Prandoty. W 1398 r. sąd nakazal braciom okazać dok. w sprawie pieniędzy (czyli dok. króla Kazimierza, SP 8, uwaga 231/58, 242/92, 268/71, 270/96, 271/57, 284/19, 286/11, 288/23, 291/20, nr 7535). Dziedzice Sąspowa herbu Drużyna zadbali o prawo niemieckie dla tej wsi. W 1439 r. sąd grodzki krakowski odesłał kmieci z Sąspowa do 
sądu we wsi według prawa niemieckiego, ponieważ dziedzic Spytek okazał dok. W sprawie tego prawa - privilegium [...] presentavit et ad legendum prebuit quo lecto et audito ipsum circa ius supradictum pro kmethonibus per ipsum iudicandis remansimus (CC 6, s. 298). Nie wykluczone, że zezwolenia na prawo niemieckie udzielił Kazimierz Wielki.

37. Przed 1370 r. król na prośbę Dzierslawa z Chrząstowic i Stogniewic nadaje prawo niemieckie wsiom do niego należącym.

Wzm. z 1413 r.: Mściszek z Gór w sporze z kmieciami z Lękawy dok. króla Polski Kazimierza udowodnil, że jego wieś Stogniewice posiada prawo niemieckie (TC 193, s. 149).

Uw. W czasach Kazimierza Wielkiego Stogniewice należały do poświadczonego od 1331 r. Dziersława, który w latach 1336-1370 pełnił urząd stolnika krakowskiego (Urzednicy malopolscy, s. 118; SHG, cz. 1, s. 383, 384). Dopiero w końcu XIV stulecia wieś ta należała do Obulców. Wiele lat później ponowione zostało prawo niemieckie dla Stogniewic. W 1475 r. Kazimierz Jagiellończyk nadał to prawo należącym do Mikolaja Kreydlara - burgrabiego, rajcy i celnika krakowskiego, wsiom Stogniewice i Skrzeszowice (Kartoteka Pracowni).

38. Przed 1370 r. król nadaje wsi Tczycy prawo niemieckie, a dziedzicom - immunitet sądowy.

Wzm. z 1411 r.: Szczepan z Tczycy w sporze z Janem z Raszkowa przedłożył w sądzie ziemskim dok. króla Kazimierza na prawo niemieckie (TC 193, s. 60).

Uw. Jan miał wówczas część w Tczycy, której pozbyl się w $1420 \mathrm{r}$. (KDK 2, nr 598). Był ożeniony ze Stachną - córką Szczepana i Wichny (SP 8, nr 6002-6004). Szczepan herbu Topór pisal się z: Tczycy, Płazy, Żarnowca i Swojczan. W tej ostatniej wsi solectwo bylo poświadczone w $1410 \mathrm{r}$. (KSN, nr 2658). W 1412 r. sąd skazał Stanisława - karczmarza ze Swojczan, na kare 6 skojcy na rzecz podsędka krakowskiego, ponieważ nie okazał mu dok. na prawo niemieckie (TC 193, s. 104). W 1411 r. Szczepan okazal zaginiony dok. Kazimierza Wielkiego w sprawie tego prawa dla wspomnianych wsi. Nie wiadomo, dlaczego nie udostępnił go karczmarzowi.

39. Przed 1370 r. król przenosi na prawo magdeburskie wieś rycerską Witowice $\mathrm{w}$ powiecie sądeckim.

Wzm. z 1428 r.: Wiernek z Gabania w sporze z Andrzejem Chebdą na rokach $\mathrm{w}$ Czchowie okazał dok. króla Kazimierza, quod omnes et singuli kmethones sui in Vittouicze nullibi debent respondere nisi iure magdeburgensi (TCz. 3, s. 43).

Uw. Pierwsze wiadomości o Witowicach poczynają się od 1398 r. (SP 8, nr 11010 i uwaga 253). W końcu XIV stulecia we wsi było już kilku dziedziców. Trudno wskazać ewentualnego odbiorcę dok. Kazimierza. Wiernek z Gabania skupowal części w Witowicach od ok. 1428 r. Na przykład 
w latach 1430-1432 kupowal części w Witowicach i Parkoszówce (TCz. 3, s. 66; Kartoteka Pracowni).

40. Przed 1370 r. król nadaje przywileje $\mathrm{z}$ immunitetem sądowym niektórym $\mathrm{z}$ dziedziców Zręczyc.

Wzm. z 1429 r.: 27 września sąd ziemski zawyrokował, że Piotr ze Stadnik ma złożyć i zdeponować przysługujący szlachetnemu Słodkowi (Slodconis) i jego braciom - dziedzicom części w Zręczycach, dok. pod pieczęcią króla Kazimierza na ręce kasztelana krakowskiego Krystyna w obecności króla Wladysława po jego najbliższym przyjeździe do Niepołomic. Gdyby ten dok. nie został okazany, wspomniani szlachcice utracą w całości wszystkie te prawa, które on zawiera (TC 9, s. 111). Piotr przedłożył ten dok., poniewaź nie był później kontynuowany jego spór z dziedzicami Zręczyc. W 1444 r. zostal poświadczony Nicolaus dictus Sodlek filius Szodlek (TC 12 , s. 212, 246; SP 7, nr 809). Sądzę, że w 1429 r. pisarz błędnie zapisal Slodconis, zamiast Sodlconis.

W Zręczycach sprawy własnościowe były wyjątkowo skomplikowane. Dziedziny były rozdrobnione, a niektórzy $z$ wlaścicieli jeszcze $w$ drugiej połowie XV w. nie mieli prawa rycerskiego. Części w tej wsi należały nawet do znaczniejszych szlachciców. Swoich służebników mieli tam Stadniccy z rodu Drużynów. Spora część wsi należała do Niewiarowskich herbu Półkozic, których przedstawicielem od końca XIV w. był wojewoda lęczycki Jan Ligęza. W 1433 r. jego potomek Jan Niewiarowski dwukrotnie wyjmował swoich kmieci z Niewiarowa, Zborczyc i Zręczyc spod jurysdykcji grodzkiej opatrzonym średnią pieczęcią dok. króla Władysława Jagiełly $\mathrm{w}$ sprawie prawa niemieckiego dla tych wsi (CC 4, s. 978, 1046). W Zręczycach byly skomplikowane nie tylko sprawy własnościowe, ale sytuacja prawna. Po lokacji na prawie niemieckim przez Ligęzę część Zręczyc została przekształcona w osobną wieś. Bardzo ważne i ciekawe wiadomości dotyczące dóbr Niewiarowskich pochodzą z 1426 r., kiedy Katarzyna Niewiarowska - wdowa po Mikołaju z Niewiarowa, była zachodźcą szlachetnego Jakuba z Sułowa w sporze z Rafałem - sołtysem z Zalesia, o dwa woły. Miała ona okazać litteram iuris supremi scultettorum Adama z Jaworznika, Mikolaja z Lipnika, Grzegorza z Janiszówki i Macieja z Kasiny i Andrzeja ze Zręczyc oraz innych sołtysów przeciw Rafałowi, quod illud quod recepit eidem Raphaelt predicta nobilis Katherina recepit in penis suis quas eadem dicti sculteti decreverunt. Następnie Katarzyna miała stawić w sądzie grodzkim tych soltysów i Andrzeja z Rabki oraz Jana ze Świdówki, qui debent litteram suam expurgare pro contentis in libro (CC 2, s. 680, 694). Siedmiu zatem soltysów z jej dóbr zasiadało $w$ sądzie leńskim $w$ rozleglych dobrach szlacheckich, rządzących się prawem niemieckim. 